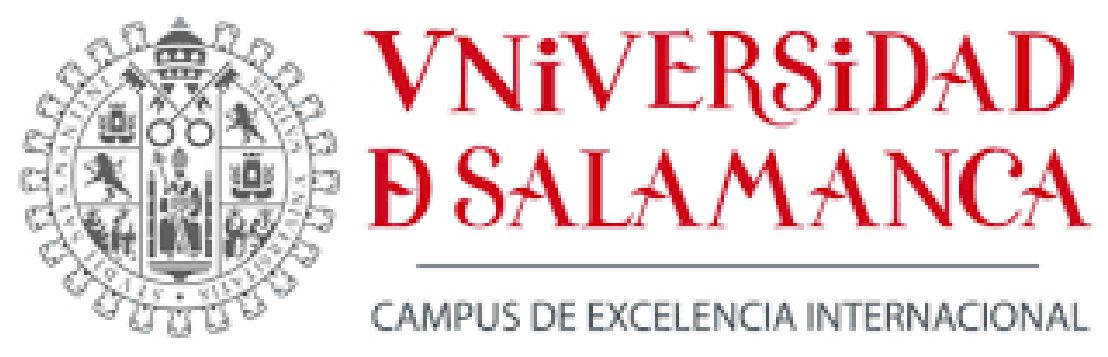

TESIS DOCTORAL

Da Periferia à Fronteira: Povoamento do Médio Côa entre os séculos X e XII

Tiago Pinheiro Ramos

Dirigida por:

Dr. Iñaki Martín Viso

Dra. Catarina Tente

Salamanca, 2020 


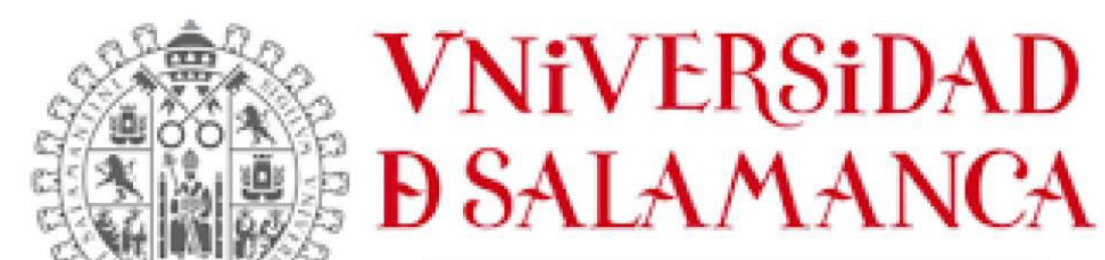

CAMPUS DE EXCELENCIA INTERNACIONAL

TESIS DOCTORAL

\section{Da Periferia à Fronteira: Povoamento do Médio Côa entre os séculos X e XII}

Tesis doctoral presentada por D. Tiago Pinheiro Ramos para optar al grado de

Doctor en Historia Medieval, Moderna, Contemporánea y de América

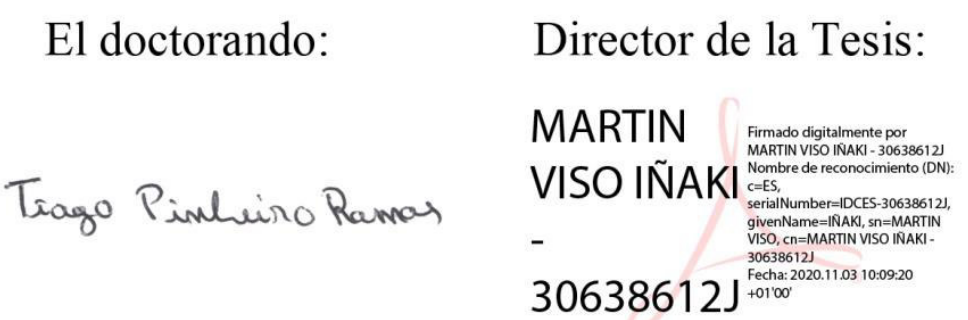

Tiago Pinheiro Ramos Dr. Iñaki Martín Viso
Directora de la Tesis:

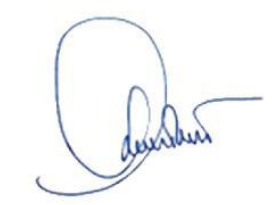

Dra. Catarina Tente

Salamanca, 31 de octubre de 2020 
Ao Agostinho e à Licínia.

Á Adriana. 
Agradecimentos

Uma tese de doutoramento é muito mais que uma investigação individual. Resulta sobretudo de um cruzar de vários e diferentes contributos pessoais, colectivos e institucionais que possibilitaram a criação de um caminho a percorrer no avanço da Ciência e do Conhecimento Histórico de um território. Nas próximas linhas quero expressar a minha gratidão, e o meu mais sincero bem-haja, a todos os que contribuíram para esta investigação.

Em primeiro lugar quero agradecer aos meus dois orientadores de doutoramento, Professor Iñaki Martín Viso e Professora Catarina Tente. Por me terem aceitado como orientando, pelas inúmeras aportações metodológicas, críticas construtivas e correcções que permitiram que esta tese suplantasse o inicialmente escrito e diminuísse os pontos negativos, por não terem desistido de alguém que tem um grave problema com o cumprimento de prazos. A um nível mais particular deixo também o meu sentido agradecido ao Professor Iñaki pela sempre pronta ajuda nas questões burocráticas relacionadas com o Doutoramento na Universidade de Salamanca e sem a qual poderia ter incorrido mais que uma vez em imbróglios administrativos de difícil resolução. À Professora Catarina por me ter acolhido e inserido ao longo destes anos na investigação sobre a Arqueologia Medieval, pela amizade sincera que lhe permite dar uns "puxões de orelhas" quando necessário, e sobretudo por em 1998 ter contribuído, inadvertidamente, para que um miúdo de 9 anos pensasse em ser arqueólogo.

A nível académico um agradecimento institucional à Universidad de Salamanca pelas condições, sobretudo ao nível da sua biblioteca, que permitiram o acesso a uma tão vasta bibliografia dedicada ao período medieval. Também a este nível um agradecimento ao Instituto de Estudos Medievais da Universidade Nova de Lisboa pelo acolhimento enquanto instituição, e pelo contributo de alguns dos seus investigadores na discussão de alguns dados sobretudo do foro historiográfico.

A nível institucional agradecer em primeiro à Fundação para a Ciência e Tecnologia, pela bolsa de doutoramento (SFRH/BD/129777/2017) que me foi atribuída e a qual possibilitou a dedicação em exclusividade aos trabalhos de investigação necessários à realização deste estudo.

Igualmente, a nível institucional, um agradecimento à Câmara Municipal da Guarda, à Junta de Freguesia de Jarmelo São Pedro, e à Associação Hereditas, os quais disponibilizaram meios logísticos e humanos que possibilitaram a realização de duas 
campanhas de escavação arqueológica no Castro do Jarmelo, com a participação de alunos de arqueologia e de jovens voluntários do concelho da Guarda.

A propósito dos diferentes trabalhos arqueológicos realizados no decorrer desta investigação um agradecimento especial aos colegas que aceitaram ser investigadores auxiliares do PIPA MEDCÔA. Ao Vítor Pereira por desde 2013 ter demonstrado todo o empenho em que estudasse os materiais das suas intervenções quer no Jarmelo como no restante concelho da Guarda, pela imensa bibliografia disponibilizada e pelos momentos de partilha de gabinete e obras camarárias. Á Sara Prata e ao Fabián Cuesta pelas suas sugestões e conselhos sempre muito cerebrais, e por me terem mostrado que existem sítios e pessoas interessantes no Alto Alentejo. Ao João Araújo, companheiro desde o primeiro dia de Faculdade de Letras (eles é que ficaram a perder!), por toda a camaradagem, partilha, e discussões tendencialmente hermenêuticas, sobre metodologias arqueológicas, materiais cerâmicos, e a vida na periferia.

Também dentro da componente arqueológica um especial agradecimento à Beatriz Fonte pela total partilha de dados relativos ao concelho de Almeida, exemplo máximo de que só trabalhando em conjunto conseguimos um melhor conhecimento do território. Ao Gonçalo Jacinto, elemento chave nas campanhas de escavação realizadas na Vigia e no Castro do Jarmelo em 2019. Ao Tiago Gil e ao José Paulo Francisco pela camaradagem essencial para a realização da difícil, mas altamente proveitosa, intervenção no Castelo da $\mathrm{Sr}^{\mathrm{a}}$ de Monforte. Ao Professor André Teixeira pela disponibilidade no acesso aos materiais das escavações de Almeida. À Alcina Cameijo pela cedência de dados e interpretações sobre a intervenção na Torre Velha da Guarda. Á empresa ArqueoHoje pela pronta disponibilidade de acesso e condições de estudo dos materiais da intervenção nos Castelos Velhos. E por último, um enorme bem-haja aos inúmeros habitantes do Médio Côa, guardiões de saberes ancestrais que na sua enorme boa-vontade me auxiliaram com indicações preciosas nos trabalhos de prospecção e relocalização de sítios arqueológicos.

Num cenário mais pessoal, um sincero agradecimento a toda a minha família que sempre apoiaram as minhas escolhas profissionais e académicas, e por todo o trabalho, muitas vezes invisível, a criar condições e a "segurar as pontas" para que nada me faltasse desde sempre. Sei perfeitamente que terão um enorme orgulho no "doutorzinho".

Não poderia deixar de referir o contributo dos amigos que considero como família. Sofia Rodrigues, Henrique Queiroz, Mário Marcelino, Sofia Godinho, Marta 
Pinto, Pedro Costa, Sara Rebelo, e a mais recente e maravilhosa aquisição Joana Rebelo Costa. Todo o vosso apoio logístico nas idas, vinda e estadias permitiram um reconforto para quem tenta fazer investigação estando longe dos grandes centros académicos. Que continuemos os mesmos parvos por muitos e bons anos.

Reservo as últimas palavras para a Sílvia. Não só pelo enorme apoio ao longo destes quatro anos nos trabalhos de prospecção, escavação, inventário, tratamento de materiais, que permitiram que esta tese não se arrastasse ainda mais no tempo. Mas sobretudo por conseguires na tua maneira intempestiva e mélico pôr um pouco de ordem neste meu caos. 


\section{Da Periferia à Fronteira: Povoamento do Médio Côa entre os séculos X e XIII}

Resumo: Esta dissertação tem como objecto de estudo a análise do povoamento medieval no território do Médio Côa em período medieval, num intervalo de tempo entre os séculos X e XIII, e a compreensão da génese deste rio como linha de fronteira. A área em estudo, foi definida tendo por base a divisão trifásica da bacia hidrográfica do rio Côa, ao qual se aliou o território transcorrido pelas ribeiras de Tourões e de Rio Seco, um território que corresponde ao final do planalto mesetenho.

A metodologia deste trabalho assentou primordialmente numa abordagem de índole arqueológica a qual foi complementada com o contributo de dados históricos e análises em ambiente SIG. Apresentam-se assim os dados revistos de anteriores intervenções arqueológicas realizadas neste território aos quais se aliam os resultados inéditos dos trabalhos de prospecção e escavação arqueológica realizados no âmbito do PIPA MEDCOA. Estes foram, sempre que possível, correlacionados com as fontes documentais transcritas e complementados como análises SIG, numa análise diacrónica sobre a evolução das estruturas de povoamento em época medieval.

A presença de sepulturas rupestres e as correlações com vestígios materiais e estruturais demostram a presença efectiva de ocupação humana do território e sua exploração. Porém denota-se a existência de um espaço periférico durante a Alta Idade Média, proliferando formas autárcicas de organização do território, sobretudo assentes numa escala local. Esta escala é também evidente em período posterior, nomeadamente durante a Plena Idade Média. Não obstante é agora evidente um processo de articulação do território num âmbito supralocal. Este processo, realizado pro agentes externos, apoiar-se-á na pré-existências de hierarquias de poder existente já no território, integrando-as ou transformando-as. É neste âmbito que se deve também entender a génese do rio Côa como linha de fronteira entre dois reinos em processo de expansão e consolidação territorial. Mais que uma linha traçada no território este é principalmente um marco conceptual de fácil apropriação quer por agentes supralocais como pelas populações locais. Contudo, e apesar de a disputa e alteração da fronteira nos finais do século XIII terem dado alguma relevância ao território, o sua principal característica periferia - tenderá a não se alterar.

Palavras-chave: Arqueologia; Alta Idade Média; Plena Idade Média; povoamento medieval; territórios periféricos; Fronteira; Médio Côa. 


\section{De la periferia a la frontera: poblamiento del Médio Côa entre los siglos X y XIII}

Resumen: La presente Tesis Doctoral tiene como objeto de estudio el análisis del asentamiento medieval en el territorio del Côa Medio en la época medieval, en un intervalo de tiempo entre los siglos X y XIII, y la comprensión de la génesis de este río como línea fronteriza. El área en estudio se definió a partir de la división en tres fases de la cuenca hidrográfica del río Côa, a la que se agregó el territorio atravesado por los arroyos Tourões y Río Seco, territorio que corresponde al final de la meseta.

La metodología de este trabajo se basó principalmente en un enfoque arqueológico que se complementó con el aporte de datos históricos y análisis en un entorno SIG. Así, se presentan los datos revisados de intervenciones arqueológicas previas realizadas en este territorio, junto con los resultados inéditos de los trabajos de prospección y excavación arqueológica realizados en el ámbito de PIPA MEDCOA. Estos se correlacionaron, siempre que fue posible, con las fuentes documentales transcritas y se complementaron como análisis SIG, en un análisis diacrónico sobre la evolución de las estructuras de asentamiento en época medieval.

La presencia de tumbas de excavadas e las rocas y sus correlaciones con materiales y estructurales demuestran la presencia efectiva de ocupación humana del territorio y su explotación. Sin embargo, se trata de un espacio periférico durante la Alta Edad Media, con la proliferación de formas autónomas de organización territorial, fundamentalmente em una escala local. Esta escala también es evidente en un período posterior, a saber, durante la Edad Media. Sin embargo, ahora es evidente un proceso de articulación del territorio a nivel supralocal. Este proceso, realizado por agentes externos, se basará en la preexistencia de jerarquías de poder existentes en el territorio, integrándolas $\mathrm{o}$ transformándolas. Es en este contexto que la génesis del río Côa debe también entenderse, una línea fronteriza entre dos reinos en proceso de expansión y consolidación territorial. Pero más que una línea trazada en el territorio, se trata principalmente de un marco conceptual que puede ser apropiado tanto por agentes supralocales como por poblaciones locales. Sin embargo, y a pesar de que la disputa y alteración de la frontera a finales del siglo XIII ha dado cierta relevancia al territorio, su principal característica, la periferia, tenderá a no cambiar.

Palabras-clave: Arqueología; Alta Edad Media: Plena Edad Media; poblamiento medieval; territorios periféricos; Frontera; Medio Côa 


\section{From the periphery to the frontier: Medieval settlement of the Middle Côa between the 10th and 13th centuries}

Abstract: This Thesis has as object of study the analysis of the medieval settlement in the Middle Côa territory in the medieval period, in a time interval between the 10th and 13th centuries, and the understanding of the genesis of this river as a frontier line. The area under study was defined based on the three-phase division of the hydrographic basin of the Côa River, to which the territory crossed by the Tourões and Rio Seco streams was added, a territory that corresponds to the end of the meseten plateau.

The methodology of this work was based primarily on an archaeological approach which was complemented with the contribution of historical data and analysis in a GIS environment. Thus, the revised data from previous archaeological interventions carried out in this territory are presented, together with the unprecedented results of the archaeological prospecting and excavation work carried out within the scope of PIPA MEDCOA. These were, whenever possible, correlated with the transcribed documentary sources and complemented as GIS analyzes, in a diachronic analysis on the evolution of settlement structures in medieval times.

The presence of rock cut graves and the correlations with material and structural traces demonstrate the effective presence of human occupation of the territory and its exploitation. However, there is a peripheral space during the High Middle Ages, with autarchic forms of territorial organization proliferating, mainly based on a local scale. This scale is also evident in a later period, namely during the beginning of Late Middle Ages. However, a process of articulating the territory at a supralocal level is now evident. This process, carried out by external agents, will be based on the pre-existence of existing hierarchies of power in the territory, integrating or transforming them. It is in this context that the genesis of the Côa River must also be understood as a border line between two kingdoms in the process of territorial expansion and consolidation. More than a line drawn in the territory, this is mainly a conceptual framework that can be appropriated both by supralocal agents and by local populations. However, and despite the dispute and alteration of the frontier at the end of the 13th century having given some relevance to the territory, its main characteristic - periphery - will tend not to change.

Keywords: Archeology; High Middle Ages; Late Middle Ages; medieval settlement; peripheral territories; Border; Middle Côa. 


\section{Índice}

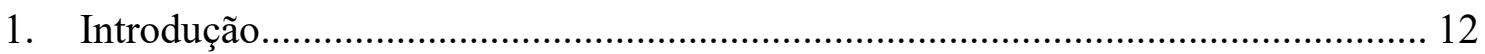

1.1. Organização interna da dissertação ................................................................... 13

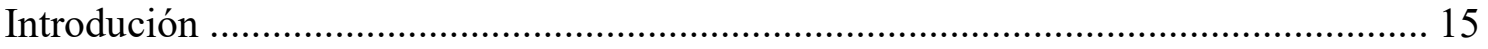

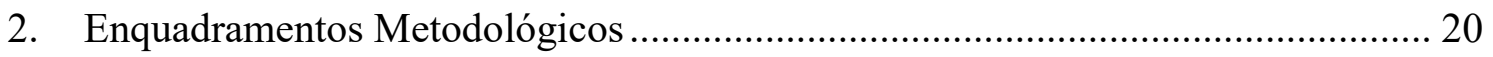

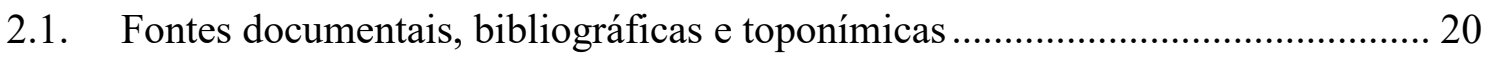

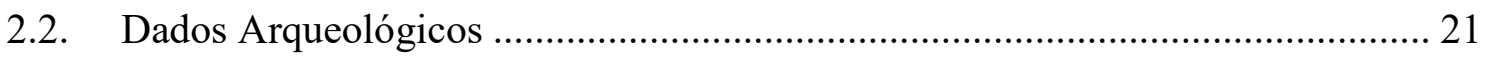

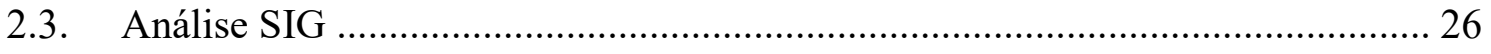

2.4. Organização e apresentação de dados ............................................................... 28

2.5. Os conceitos de Periferia e Fronteira aplicados à praxis arqueológica ............... 29

3. O Espaço - a definição do Médio Côa ………............................................................... 38

4. O Espectro Temporal: Entre o início do Século X e o final do Século XIII ............... 46

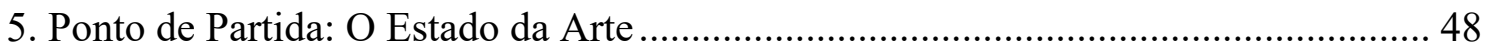

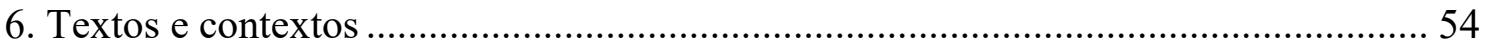

6.1. As fontes documentais no Médio Côa ..................................................................... 54

6.1.1. A documentação dos séculos XII e XIII da margem direita do Médio Côa.......... 56

6.1.2. A documentação entre o século XII e XIII da margem esquerda do Médio Côa. 62

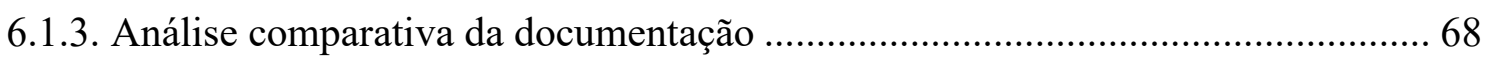

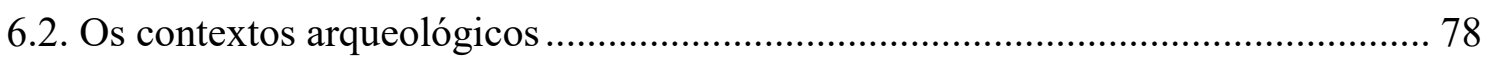

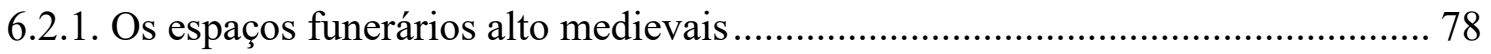

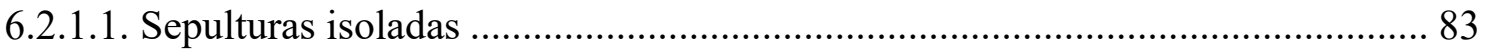

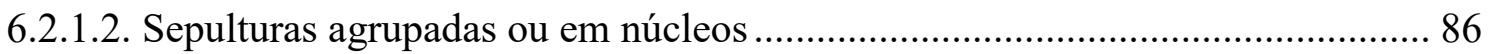

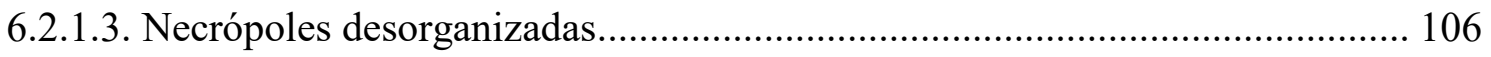

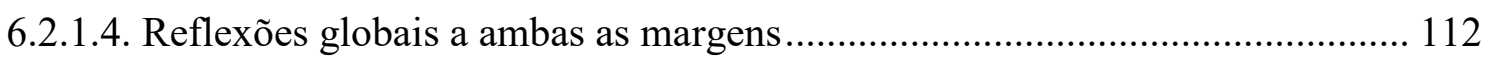

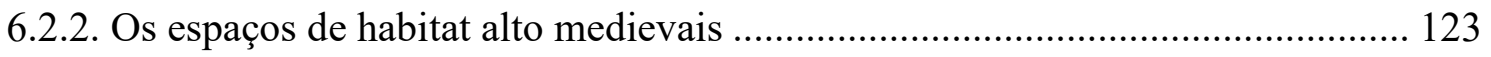

6.2.2.1. Sítios romanos com continuidade e/ou reocupação em período alto e pleno

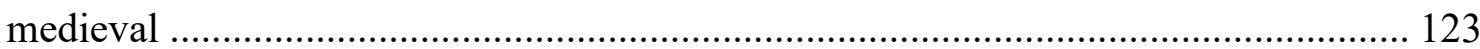

6.2.2.2. Vestígios de habitats e materialidades alto medievais................................... 134

6.2.2.3. Vestígios de habitats e (possíveis) estruturas alto medievais ......................... 137

6.2.2.4. Vestígios de habitats de cronologia indeterminada ....................................... 143

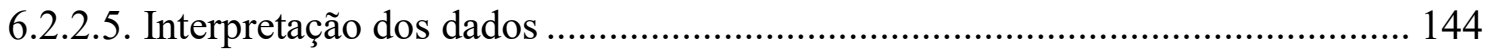

6.2.3. Estruturas de povoamento nos séculos XII-XIII ............................................ 152

6.2.4. Vilas amuralhadas, povoados fortificados, e sítios de altura............................. 172

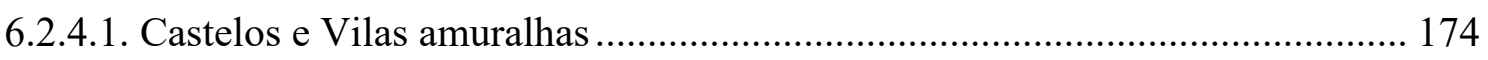




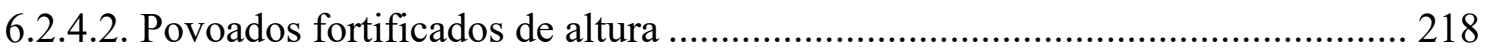

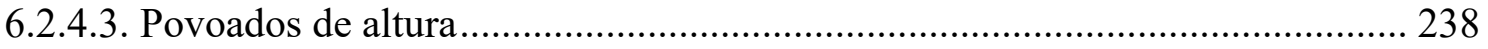

6.2.4.4. Análise conjunta dos povoados fortificados e de altura ............................... 240

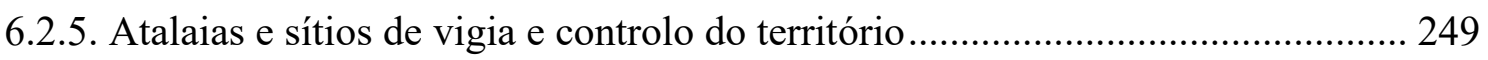

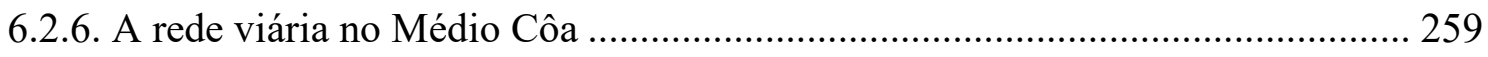

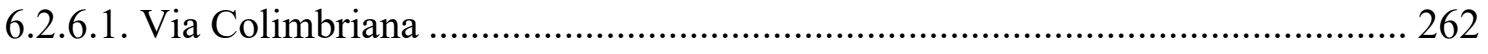

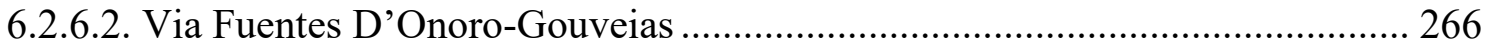

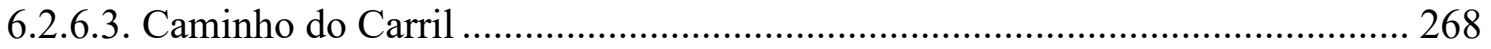

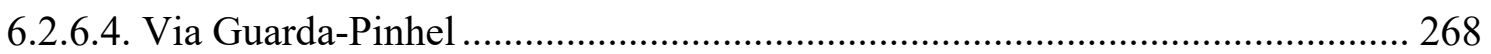

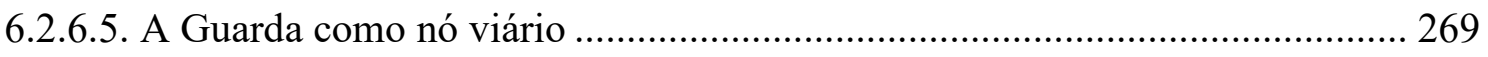

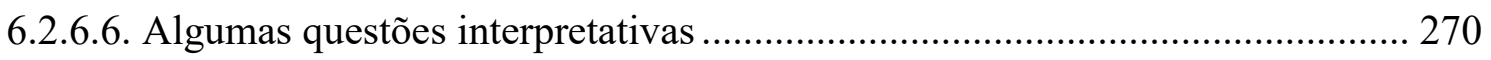

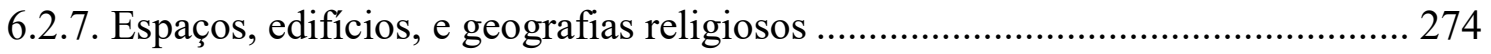

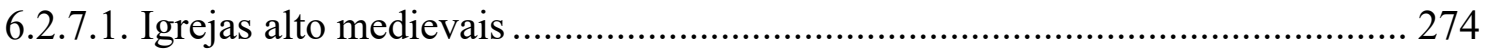

6.2.7.1.1. Igreja de Santa Maria do Jarmelo, dados e interpretações ........................... 276

6.2.7.2. Igrejas e Paróquias na Plena Idade Média ..................................................... 285

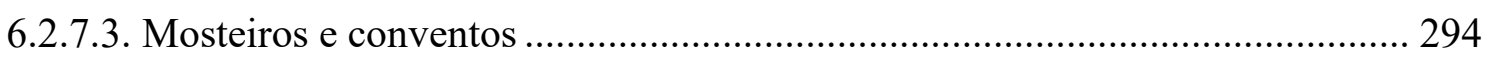

6.2.7.4. Organização diocesana do Médio Côa ............................................................. 299

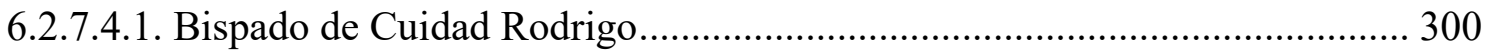

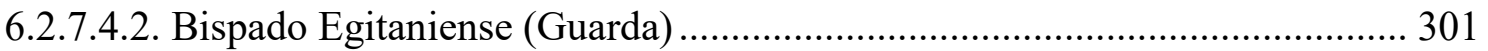

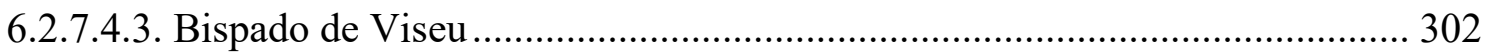

7. Da periferia à fronteira. Um ensaio de longa diacronia no Médio Côa em período

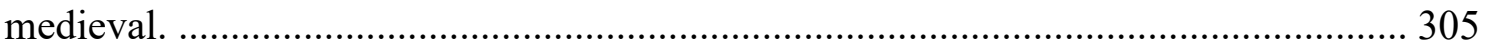

8. Considerações finais e linhas de investigação futuras ............................................... 325

Consideraciones finales y líneas de investigación futuras ......................................... 329

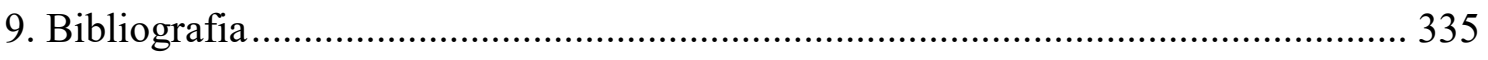




\section{Introdução}

Ciclicamente a região do Vale do Côa é alvo de atenção por parte de agentes externos ao território. Quer falemos dos Centros Políticos, quer consideremos a própria Academia. Se no primeiro caso normalmente está associado aos ciclos legislativos, o segundo resulta sobretudo de uma reacção a acontecimentos locais. Porém são raras as circunstâncias em que estes dois agentes se entrecruzaram para benefício da região, das suas comunidades, e do seu conhecimento histórico. Ressalvam-se, no entanto, dois momentos: a preservação e estudo da arte rupestre do Vale do Côa; e numa dimensão menor, os projectos de valorização e investigação dos monumentos e espaços medievais associados ao contexto identitário do Tratado de Alcanices. Se o primeiro momento deteve uma continuação ao longo dos últimos 25 anos encontrando-se actualmente ${ }^{1}$ implantando e reconhecido a nível nacional e internacional, o segundo momento parecenos que, salvo raras excepções, estagnado no tempo. Escasseavam os trabalhos de investigação no terreno, e as narrativas historiográficas perpetuavam o conhecimento anteriormente alcançado sem grandes aportações de novos dados, e principalmente hipóteses de interpretações diferentes.

Foi esta premissa, aliada ao nosso sentimento identitário com este território, que nos levaria em 2015 a dar início a este projecto de investigação sobre o passado medieval da região. Como no princípio de qualquer trabalho científico definimos dois objectivos principais: a identificação e compreensão da estrutura de povoamento da região; e a percepção da génese da concepção do Rio Côa como linha de fronteira.

Para o cumprimento desta tarefa, ou pelo menos uma maior proximidade possível aos objectivos, definiu-se uma metodologia predominantemente arqueológica e conjugada, sempre que possível, como os dados históricos existentes. O objectivo proposto seria colmatar as falhas de conhecimento em ambas as disciplinas de forma a ser criado um discurso narrativo histórico, o mais abrangente, complementar, e multidisciplinar possível.

No entanto, face à envergadura do território relacionado com o Rio Côa, que considerávamos demasiado lato para se conseguir estudar de forma uniforme, decidimos reduzir esta escala. Assim, optamos por abordar apenas o Médio Côa (Fig.3.1), espaço delimitado no capítulo 3, que corresponde a um terço do território, viável de se

\footnotetext{
${ }^{1} \mathrm{O}$ corpo deste texto foi redigido em Língua Portuguesa não seguindo a ortografia imposta pelo novo Acordo Ortográfico (AO90).
} 
enquadrar como um case study, e passível de ser a posteriori aplicável a todo o Vale do Côa.

Definido o Espaço era imprescindível definir também o Tempo. Identicamente, neste passo considerámos pouco viável abarcar um tão lato espectro temporal como seria toda a Idade Média, ou seja, cerca de um milénio. Não se pretendia uma análise de tão longa diacronia. Mais ainda atendendo ao segundo objectivo enumerado. Neste contexto detínhamos um marco simbólico para o fim da baliza temporal de análise: o Tratado de Alcanices, ou seja o final do século XIII. Mas como argumentaremos no capítulo 4, o estabelecimento do marco de partida, o século $\mathrm{X}$, será sobretudo uma demarcação artificial.

Por último, e antes de entrarmos nas questões organizativas desta dissertação, cabe-nos fazer uma pequena advertência relacionada com a posição teórica utilizada no decorrer da investigação. Esta posição, de forma igual que a metodologia, território, e cronologias, foi uma escolha deliberado e ponderada pelo autor. Concretamente referimo-nos à conceptualização e aplicação dos conceitos de Periferia e Fronteira à metodologia de análise, e mormente às interpretações dos dados. A sua aplicação denotou-se desde o início tangível e notoriamente essencial para a compreensão dos processos, socioeconómicos e geopolíticos, pelos quais estes territórios, e as suas comunidades, se estariam a conduzir e adaptar.

\subsection{Organização interna da dissertação}

Estruturalmente e formalmente, o presente trabalho encontra-se dividido em oito partes. Desde logo a primeira corresponde à presente introdução onde se mencionam os objectivos gerais que nortearam esta investigação, e se aclara a estrutura interna.

O capítulo 2 é dedicado às opções metodológicas tomadas como pontos orientadores no decurso da investigação. Por se tratar de diferentes, embora complementares, metodologias o mesmo foi subdividido em quatro partes. As três primeiras referentes às questões da forma como se adquiriram e enquadraram os diferentes dados, nomeadamente: fontes documentais, bibliográficas e toponímicas; dados arqueológicos; e análises em ambiente SIG. A estes será adscrito um quarto ponto relativo à própria organização e apresentação dos dados, e um quinto ponto sobre a conceptualização dos conceitos de Periferia e Fronteira empregues ao longo desta dissertação. 
O terceiro capítulo abarca a definição do território. Inicialmente com a descrição e justificação dos limites geográficos do Médio Côa, e numa segunda parte a caracterização da geomorfologia, hidrologia e pedogénese deste espaço.

O capítulo 4 é relativo à também definição da baliza cronológica de análise deste território, e à fundamentação dos critérios que nos levaram a estabelecer marcos cronológicos teóricos de fácil apreensão num discurso peninsular.

No quinto capítulo pretendeu-se abordar de forma sumária o estado da investigação anteriormente existente. De forma crítica analisaram-se as correntes historiográficas prevalentes, as suas linhas de investigação, e sobretudo a manifesta inexistência de um discurso transversal e multidisciplinar entre dois períodos históricos (Alta e Plena Idade Média).

O sexto capítulo é aquele onde se expõem e interpretam o volume de dados coligidos. Face à sua quantidade, diferenciação, e cronologias, estes foram subdivididos consoante a sua tipologia. Assim no primeiro subcapítulo foram examinadas as fontes documentais transcritas. Inicialmente realizou-se uma breve abordagem à documentação alto medieval de áreas limítrofes, e em seguida focada nos documentos existentes para a região em estudo. Esta foi feita de forma global, conciliando os documentos referentes às duas margens, e com uma breve análise dos dados e processos possíveis de analisar. Estes seriam posteriormente, ao longo dos restantes capítulos, referidos por forma a complementar as análises. O segundo subcapítulo foi dedicado aos sítios, espaços, e contextos que detinham vestígios ou referências de época medieval. Também neste caso optamos por uma subdivisão face às diferentes tipologias: espaços funerários rupestres; habitats e povoados abertos; povoados de altura e sítios fortificados; estruturas de controlo do território; vias de comunicação; e espaços e geografias eclesiásticas. Em cada subcapítulo os dados foram analisados seguindo uma ordem cronológica evolutiva. Similarmente no final de cada um foi adscrito um espaço para as primeiras interpretações e reflexões tendo em conta uma análise do território de forma global.

No sétimo capítulo pretendeu-se realizar um ensaio sequencial e diacrónico sobre o povoamento medieval nesta região. Partindo dos dados e interpretações que ao longo da dissertação foram apresentados de forma separada, foi realizado uma narrativa histórica tendo em conta os resultados atingidos.

Por último, o capítulo 8 foi dedicado às considerações finais possíveis face aos objectivos iniciais traçados. Mais que a explanação dos resultados foram abordadas as ainda lacunas decorrentes deste trabalho, transmutadas em questões e agenda de futuro. 
Para além deste corpo de texto, no qual se inserem sobretudo mapas representativos dos espaços e sítios que se estão a abordar em cada capítulo, optou-se pela inserção das restantes figuras, tabelas e desenhos e catálogos de sítios em anexos, seguindo a ordem pela qual no texto os sítios vão sendo abordados. O Anexo I é composto por um corpus de cartografia complementar à inserida no texto. O Anexo II é formado pelo conjunto de tabelas que incorporam todos os dados analíticos e factores ponderados nas análises dos sítios incorporados no catálogo de sítios arqueológicos definidos na metodologia como Grupos 1 e 2. O Anexo III incorpora todos os registos gráficos e fotográficos, que foi possível coligir, relativo aos sítios e contextos analisados. Similarmente se encontra organizado seguindo a ordem progressiva dos capítulos. Por último, no Anexo VII apresenta-se a lista de abreviaturas utilizadas ao longo do texto, tornando este um pouco mais fluido e menos repetitivo.

\section{Introdución}

Cíclicamente, la región del Valle del Côa es objeto de atención por parte de agentes externos al territorio. Tanto si hablamos de los Centros Políticos como si consideramos la propia Academia. Si en el primer caso suele estar asociado a ciclos legislativos, el segundo resulta principalmente de una reacción a los acontecimientos locales. Sin embargo, las circunstancias en las que estos dos agentes se entrelazaron en beneficio de la región, sus comunidades y su conocimiento histórico son raras. Sin embargo, cabe señalar dos momentos: la conservación y estudio del arte rupestre en el Valle del Côa; y en una dimensión menor, los proyectos de valorización e investigación de monumentos y espacios medievales asociados al contexto de identidad del Tratado de Alcañices. Si el primer momento tuvo una continuación en los últimos 25 años y actualmente está implantado y reconocido a nivel nacional e internacional, el segundo momento nos parece que, salvo raras excepciones, se ha estancado en el tiempo. El trabajo de investigación sobre el terreno fue escaso y las narrativas historiográficas perpetuaron el conocimiento previamente logrado sin mayores aportes de nuevos datos, y especialmente diferentes hipótesis interpretativas.

Fue esta premisa, combinada con nuestro sentido de identidad con este territorio, la que nos llevaría en 2015 a iniciar este proyecto de investigación sobre el pasado 
medieval de la región. Como al inicio de cualquier trabajo científico, hemos definido dos objetivos principales: la identificación y comprensión de la estructura del poblamiento medieval en la región; y la percepción de la génesis del Río Côa como línea fronteriza.

Para lograr esta tarea, o al menos acercarnos lo más posible de los objetivos, se definió una metodología predominantemente arqueológica y combinada, siempre que fue posible, como los datos históricos existentes. El objetivo propuesto sería llenar los vacíos de conocimiento en ambas disciplinas para crear un discurso narrativo histórico, lo más completo, complementario y multidisciplinario posible.

Sin embargo, dado el tamaño del territorio relacionado con el río Côa, que consideramos demasiado amplio para poder estudiarlo de manera uniforme, decidimos reducir esta escala. Así, optamos por abordar solo el Medio Côa (Fig. 3.1), espacio definido en el capítulo 3, que corresponde a un tercio del territorio, viable para encajar como caso de estudio, y susceptible de ser aplicable a posteriori a todo el Vale do Côa.

Una vez definido el Espacio, también era fundamental definir el Tiempo. Asimismo, en este paso, consideramos inviable cubrir un espectro temporal tan amplio como lo sería toda la Edad Media, es decir, alrededor de un milenio. No se pretendía hacer un análisis de una diacronía tan larga. Más aún teniendo en cuenta el segundo objetivo enumerado. En este contexto, teníamos un límite simbólico para el final del marco temporal de análisis: el Tratado de Alcañices, es decir, el final del siglo XIII. Pero como argumentaremos en el capítulo 4, el establecimiento del punto de partida, el siglo X, será ante todo una demarcación artificial.

Finalmente, y antes de entrar en los temas organizativos de esta disertación, nos corresponde hacer una pequeña advertencia relacionada con la posición teórica utilizada en el transcurso de la investigación. Esta posición, así como la metodología, el territorio y las cronologías, fue una elección deliberada y considerada por parte del autor. En concreto, nos referimos a la conceptualización y aplicación de los conceptos de Periferia y Frontera a la metodología de análisis, y especialmente a las interpretaciones de los datos. Su aplicación se ha mostrado desde un principio tangible y notoriamente fundamental para comprender los procesos, tanto socioeconómicos como geopolíticos, por los que estos territorios y sus comunidades están liderando y adaptándose. 
Estructural y formalmente, el presente trabajo se divide en ocho partes. El primero corresponde a la presente introducción, donde se mencionan los objetivos generales que guiaron esta investigación y se aclara la estructura interna.

El capítulo 2 está dedicado a las opciones metodológicas tomadas como puntos rectores en el curso de la investigación. Como se trata de metodologías diferentes, aunque complementarias, se subdividió en cuatro partes. Los tres primeros se refieren a las cuestiones de cómo se adquirieron y enmarcaron los diferentes datos, a saber: fuentes documentales, bibliográficas y toponímicas; datos arqueológicos; y análisis en un entorno GIS. A estos se agregará un cuarto punto sobre la organización y presentación de los datos, y un quinto punto sobre la conceptualización de los conceptos de Periferia y Frontera utilizados a lo largo de esta tesis.

El tercer capítulo cubre la definición del territorio. Inicialmente con la descripción y justificación de los límites geográficos del Côa Medio, y en una segunda parte la caracterización de la geomorfología, hidrología y pedogénesis de este espacio.

El capítulo 4 se relaciona con la definición del marco cronológico para el análisis de este territorio, y con la justificación de los criterios que nos llevaron a establecer hitos cronológicos teóricos de fácil comprensión en un discurso peninsular.

En el quinto capítulo se pretendía abordar brevemente el estado de la investigación previamente existente. Se analizaron críticamente las corrientes historiográficas imperantes, sus líneas de investigación y, sobre todo, la manifiesta falta de un discurso transversal y multidisciplinar entre dos períodos históricos (Alta y Plena Edad Media).

El sexto capítulo es aquel donde se expone e interpreta el volumen de datos recopilados. Por su cantidad, diferenciación y cronologías, estos fueron subdivididos según su tipología. Así, en el primer subcapítulo se examinaron las fuentes documentales transcritas. Inicialmente, hubo un breve acercamiento a la documentación alta medieval de las áreas vecinas, y luego se centró en los documentos existentes para la región en estudio. Esto se hizo de forma global, conciliando los documentos referentes a los dos márgenes, y con un breve análisis de los datos y posibles procesos a analizar. Posteriormente, a lo largo de los capítulos restantes, se hará referencia a ellos para complementar los análisis. El segundo subcapítulo se dedicó a los sitios, espacios y contextos que contenían huellas o referencias de la época medieval. También en este caso optamos por una subdivisión en función de las diferentes tipologías: espacios funerarios de roca; hábitats abiertos y aldeas; pueblos altos y sitios fortificados; estructuras de control del territorio; formas de comunicación; y geografías y espacios 
eclesiásticos. En cada subcapítulo se analizaron los datos siguiendo un orden cronológico evolutivo. Asimismo, al final de cada uno, se agregó un espacio para las primeras interpretaciones y reflexiones teniendo en cuenta un análisis del territorio de manera global.

En el capítulo séptimo se pretendía realizar un ensayo secuencial y diacrónico sobre el asentamiento medieval en esta región. A partir de los datos e interpretaciones que se presentaron por separado a lo largo de la disertación, se realizó una narrativa histórica teniendo en cuenta los resultados obtenidos.

Finalmente, el capítulo 8 estuvo dedicado a las posibles consideraciones finales a la vista de los objetivos iniciales planteados. Más que la explicación de los resultados, también se abordaron las brechas derivadas de este trabajo, transmutadas en preguntas y una agenda de futuro.

Además de este cuerpo de texto, que incluye principalmente mapas representativos de los espacios y sitios que se están abordando en cada capítulo, se decidió insertar el resto de figuras, tablas y dibujos y catálogos de sitios en anexos, siguiendo el orden de que en el texto se están abordando los sitios. El Anexo I está compuesto por un corpus cartográfico complementario al insertado en el texto. El Apéndice II está formado por el conjunto de tablas que incorporan todos los datos analíticos y factores ponderados en el análisis de los sitios incorporados en el catálogo de sitios arqueológicos definidos en la metodología como Grupos 1 y 2. El Apéndice III incorpora todos los registros gráficos y fotográficos, que fue posible recopilar, con respecto a los sitios y contextos analizados. Asimismo, se organiza según el orden progresivo de los capítulos. Finalmente, el Anexo VII presenta la lista de abreviaturas utilizadas a lo largo del texto, haciéndolo un poco más fluido y menos repetitivo. 


\section{Considerações finais e linhas de investigação futuras}

Retomando o que referimos no início desta dissertação, a investigação que pretendíamos desenvolver assentava no alcance de dois objectivos principais: a identificação e compreensão da estrutura de povoamento da região (periférica) do Médio Côa entre os séculos X a XIII; e a percepção da génese da concepção do Rio Côa como linha de fronteira. Como seria de esperar, no decorrer deste processo, surgiram diferentes linhas de investigação, algumas passíveis de enquadramento, outras que se tiveram de preterir para uma abordagem num futuro, que esperemos, não muito distante. Partiremos assim de uma análise dos objectivos e decorrentes destes para a abordagem das linhas de investigação.

No primeiro ponto, uma das premissas subjacente era a realização de uma análise diacrónica, unindo dois períodos históricos, primordialmente estudados de forma separada. Esta concepção resultava sobretudo da primazia dos estudos de índole historiográfica. Partindo estritamente da visão que a documentação possibilitava, como vimos, apenas se estendia a meados do século XII mas sobretudo ao século XIII. A este cenário aliava-se a diminuta inclusão no discurso científico dos dados arqueológicos. Embora parcos e bastante inacessíveis, estes dados são obtidos sobretudo a partir dos finais da década de 90 do século passado. Face a este cenário tivemos como ensejo uma abordagem multidisciplinar tentando conjugar os dados provenientes destas duas disciplinas.

No entanto, para a realização desta proposta necessitámos definir uma baliza cronológica (séculos X a XIII). Esta revelou-se bastante artificial, à luz dos dados disponíveis, concretamente na definição do século $\mathrm{X}$ como marco de qualquer tipo de processo de estruturação do povoamento nesta região. Não que ele não exista, como se constatou na região do Alto Mondego (Tente, 2010), mas no território em análise os dados actuais são muito escassos e fragmentários, influenciando a sua percepção.

Pese embora as limitações, esta investigação permitiu aportar um maior, e mais sistemático, conhecimento sobre os vestígios da ocupação humana, em contexto rural, no período alto medieval. Não só dos sempre visíveis espaços funerários rupestres, como, sobretudo, de possíveis espaços habitacionais e produtivos, e da sua articulação com o território e a paisagem. Porém, a sua génese, caracterização, morfologia e datação continuam ainda a ser apenas latamente enquadráveis em período alto medieval. 
É neste ponto que surge a primeira linha de investigação futura. É necessário futuras intervenções arqueológicas no subsolo, quer em sítios onde constatam estruturas, como nos espaços onde apenas se vislumbram materiais à superfície. Somente conhecendo os contextos habitacionais é que será exequível compreender melhor as comunidades que habitaram este território, as suas estruturas socioeconómicas, a relação com o espaço e a sua exploração, e os motivos que as levaram a segregar os espaços funerários rupestres. Todavia, para esta tarefa já não se partirá de um ponto zero, face ao conjunto de espaços que foram passíveis de inventariar. Não obstante, esta análise dos espaços rurais terá de ser complementada com a indagação dos espaços que poderiam funcionar, ao longo desta baliza cronológica, como centros de poderes locais. Como constatámos, a materialização destes poderes é presentemente quase imperceptível no registo arqueológico. Face a esta premissa, e na senda da anterior linha de investigação, será necessário no futuro a intervenção em povoados fortificados pleno medievais para se averiguar se estes se sobrepõem a vestígios mais antigos. Complementarmente é fundamental a revisão de espólios "extraviados" decorrentes de escavações anteriores, das quais se desconhecem os relatórios de intervenção. Mas será também importante a intervenção noutros espaços, nomeadamente atalaias e povoados de altura, que poderão ter sido anteriores espaços centrais. Em todo o caso, a abordagem a estes sítios e contextos materiais deverá ser cautelosa, e livre de preconceitos, uma vez que a materialização do poder das possíveis elites locais deve transfigurar-se de forma dissemelhante a outros territórios não periféricos. Ou seja, deve-se tentar encontrar os marcadores de caracterização arqueológicas dessas elites em cada território, e não através de meras comparações com os elementos utilizados noutras regiões.

Igualmente neste primeiro objectivo principal se enquadra a premissa da evolução/transição/mutação da rede de habitats rurais alto medievais para a malha de povoamento que nos séculos XII e XIII está bem expressa na documentação. Neste ponto escasseiam-nos ainda os dados em consequentemente a compreensão do processo. Tende a percepcionar-se uma diferenciação espacial, organizativa e operativa entre estes dois mundos. Porém, a presente visão pode estar enviesada pela falta de dados arqueológicos, que nos permitiria compreender em que momentos ocorreram o despovoamento de alguns sítios alto medievais, a génese dos sítios referidos documentalmente, e a possibilidade de uma prevalência de espaços ocupados numa longa diacronia. Estas questões conduzem também à necessidade de desenvolvimento 
de uma futura linha de investigação específica. Ou seja, intervenções paralelas em sítios despovoados, em sítios documentados em época pleno medieval, e actualmente habitados, e em sítios que apresentem vestígios alto medievais, se encontrem registados em época pleno medieval, mas os quais se encontrem despovoados desde época moderna ou contemporânea. Deste modo conhecendo os três contextos, sobretudo a sua componente material, poderá ser assim também possível a identificação de outros espaços com as mesmas cronologias, principalmente em trabalhos de prospecção.

De igual modo, e no seguimento do referido no parágrafo anterior, a intervenção arqueológica nos povoados fortificados pode inferir-nos dados sobre a mesma problemática da evolução/transição/mutação e sobretudo a sua génese. Por outro lado permitirá compreender as interacções entre diferentes espaços, comunidades, e entre senhores e camponeses, ou seja, a articulação do território numa escala local e regional.

As últimas considerações referentes ao primeiro objectivo enumerado reportam já ao período pleno medieval. A estrutura de povoamento, os modelos, sistemas, agentes e massa humana é-nos bastante perceptível através dos dados documentais. Porém, ainda que a historiografia tenha tido um elevado interesse e desenvolvimento sobre este período e território, temos a noção que ainda existe algum trabalho por realizar. Concretamente referimo-nos à transcrição, estudo paleográfico e diplomático de documentos que nos podem aportar novos dados, interpretações, ou que corroborem ou refutem ideias e hipóteses, mas principalmente que permitam compreender a veracidade ou falsificação de determinados documentos. Esta premissa é fundamental, sobretudo tendo em conta que no nosso caso esta é uma área disciplinar complementar, e na qual não detemos conhecimentos para individualmente a suprimir. Consideramos assim que estamos também perante uma linha de investigação futura que não deve ser descurada, mas que fica em aberto para outros investigadores com competências específicas nestas matérias.

Aos dados históricos compelidos adicionámos os dados arqueológicos existentes e resultantes desta investigação. Não por acharmos que a Arqueologia Medieval não seja uma disciplina independente e passível de se realizar de forma autónoma, mas antes porque para o território em estudo só a conjugação das duas disciplinas possibilitaria um discurso mais uniforme face às carências de dados existentes em cada uma delas. Este casamento de dados é particularmente relevante no que se refere à estrutura do povoamento e ás estratégias de organização territorial ou administrativa. Já no que se refere aos dados arqueológicos deve-se evidenciar a sua potencialidade para a 
caracterização dos quotidianos das populações e dar luz às camadas da sociedade menos visíveis através da documentação. Não obstante, os dados arqueológicos não se encontram isentos de crítica. Por um lado, ficou patente a desigualdade de dados quer entre o mundo urbano e o mundo rural, e mesmo entre os diferentes espaços intervencionados. Por outro prisma, é óbvio que os dados sobre a própria cultura material se encontram na sua génese, ou mesmo estagnada, focalizando-se o seu estudo mediante comparações estilísticas com materiais e sítios tão distantes como Santa Cruz de Vilariça. Este cenário é bastante evidente quando um conjunto cerâmico é datado largamente como medieval, podendo corresponder quer ao início do século XII quer aos finais do século XIV. Também resultante deste cenário consideramos importante o prosseguimento de uma linha de investigação sobre a evolução crono-tipológica da cerâmica, que se deve consubstanciar através do cruzamento de contextos seguros e datações absolutas desses mesmos contextos de proveniência. A estes deve-se acrescentar uma completa caracterização estilística e tecnológica das colecções materiais identificadas, só assim será possível determinar diferenciações tecnotipológicas e traçar um quadro de referência para o território.

Em todo o caso denota-se o que vimos ao longo desta investigação debatendo: a presença de um espaço periférico e a necessidade da sua abordagem epistemológica diferenciada. A ausência de poderes centrais, ou a sua influência directa, neste espaço alocaria assim a possibilidade de uma maior diversidade de formas de organização social. Ou seja, não se verificaria a estandardização das tipologias de habitat, relações socioeconómicas e formas de exploração do território, típicas de sistemas e estados muito centralizados, como o Império Romano ou os reinos peninsulares a partir da Baixa Idade Média. Porém esta é uma visão baseada numa escala supralocal. Este espaço periférico deterá ao nível local os seus núcleos de poder e hierárquicas, e consequentemente relações centro-periferia à sua escala. Nesta conjuntura será assim necessário encontrar primeiro estas relações numa escala local, ou seja em microterritórios, e só posteriormente tentar uma abordagem a uma escala supralocal. Mais ainda para se compreender não só as relações hierárquicas mas para tentar compreender a tipologia dos "bens de consumo" de baixo valor que esta região forneceria aos centros (locais e supralocais).

Pelas linhas expostas anteriormente fica claro que o objectivo traçado não foi totalmente possível de alcançar, sendo que existem sobretudo novas questões resultantes da própria investigação. 
Em contrapartida, relativamente ao segundo grande objectivo (o Côa como fronteira) tendemos a considerar que o estado de conhecimento e os argumentos enunciados permitem uma concretização quase plena. No nosso entender, a ideia de Ribacôa sobre domínio português, antes da sua incorporação no reino leonês, resulta de uma linha cronística portuguesa, naturalmente facciosa, para legitimar a sua possessão por D. Dinis. Esta seria ao longo dos tempos perpetuada pela historiografia portuguesa, de cariz nacionalista, por forma a exaltar o feito transcendental que era a expansão do pequeno reino português à custa do vizinho reino de Castela e Leão. É, no entanto, neste espectro temporal que se deve perceber a génese do Côa como fronteira, ou seja, entre os meados do século XII e meados da centúria seguinte. Mas, mais uma vez, não necessariamente ao encontro do que a historiografia portuguesa vem exacerbando. Para a referida linha historiográfica existira uma clara imposição de duas linhas de fortificações opostas e antagónicas, por parte dos dois reinos, criando uma fronteira altamente militarizada, ideia que refutamos. Tratar-se-ia antes de um processo de incorporação de territórios sob a égide das duas monarquias, recorrendo a poderes, quer eclesiásticos, mas sobretudo laicos, localmente estabelecidos em época anterior. Estes poderes laicos acabam por se transformar em agentes régios através da criação de concelhos realengos.

Em suma, transcorridas estas linhas, mais que considerações finais, nunca elas dogmáticas, pretendeu-se a enunciação de possíveis futuras linhas de investigação. Desejou-se mais que tudo contribuir para o conhecimento histórico de uma região secularmente periférica, que só pontualmente, e decorrente de questões fronteiriças, teve em época medieval (assim como nos nossos dias) algum interesse para os poderes centrais. Porém nunca se verifica uma deslocação ou aproximação dos centros a este território.

\section{Consideraciones finales y líneas de investigación futuras}

Volviendo a lo que mencionamos al inicio de esta disertación, la investigación que pretendíamos desarrollar se basó en el logro de dos objetivos principales: la identificación y comprensión de la estructura de asentamiento de la región (periférica) del Côa Medio entre los siglos X y XIII; y la percepción de la génesis de la concepción 
del Río Côa como línea fronteriza. Como era de esperar, en el transcurso de este proceso surgieron diferentes líneas de investigación, algunas de las cuales se podían enmarcar, otras que había que pasar por alto para un acercamiento en el futuro, ojalá no demasiado lejano. Así, partiremos de un análisis de los objetivos y sus consecuencias para acercarnos a las líneas de investigación.

En el primer punto, una de las premisas subyacentes fue realizar un análisis diacrónico, uniendo dos períodos históricos, principalmente estudiados por separado. Esta concepción resultó principalmente de la primacía de los estudios de carácter historiográfico. Basada estrictamente en la visión de que la documentación hizo posible, como hemos visto, solo se extendió hasta mediados del siglo XII pero sobre todo hasta el siglo XIII. Este escenario se sumó a la menor inclusión de datos arqueológicos en el discurso científico. Aunque escasos y bastante inaccesibles, estos datos se obtienen principalmente de finales de los años 90 del siglo pasado. Ante este escenario, tuvimos la oportunidad de adoptar un enfoque multidisciplinario tratando de combinar los datos de estas dos disciplinas.

Sin embargo, para llevar a cabo esta propuesta, necesitábamos definir un marcador cronológico (siglos X al XIII). Esto resultó ser bastante artificial, a la luz de los datos disponibles, específicamente en la definición del siglo X como un hito de cualquier tipo de proceso de estructuración del asentamiento en esta región. No es que no exista, como se encontró en la región del Alto Mondego (try, 2010), pero en el territorio bajo análisis los datos actuales son muy escasos y fragmentarios, lo que influye en su percepción.

A pesar de las limitaciones, esta investigación permitió aportar un mayor y más sistemático conocimiento sobre los vestigios de la ocupación humana, en el contexto rural, en el período alto medieval. No solo de los espacios funerarios rupestres siempre visibles, sino, sobre todo, de los posibles espacios habitacionales y productivos, y de su articulación con el territorio y el paisaje. Sin embargo, su génesis, caracterización, morfología y datación todavía se ajustan ampliamente al período medieval alto.

Es en este punto donde aparece la primera línea de investigación futura. Se necesitan futuras intervenciones arqueológicas bajo tierra, ya sea en lugares donde se encuentran estructuras, o en espacios donde solo se puedan ver materiales en la superficie. Solo conociendo los contextos habitacionales será posible comprender mejor las comunidades que habitaban este territorio, sus estructuras socioeconómicas, la relación con el espacio y su explotación, y las razones que las llevaron a segregar los 
espacios funerarios. Sin embargo, para esta tarea, ya no comenzará desde un punto cero, dado el conjunto de espacios que se podrían inventariar. Sin embargo, este análisis de los espacios rurales deberá complementarse con la indagación de espacios que podrían funcionar, en esta marca cronológica, como centros de poderes locales. Como hemos visto, la materialización de estos poderes es ahora casi imperceptible en el registro arqueológico. Teniendo en cuenta esta premisa, y en línea con la línea de investigación anterior, será necesario en el futuro intervenir en pueblos medievales fortificados para ver si se solapan con vestigios más antiguos. Además, es fundamental revisar los bienes "perdidos" resultantes de excavaciones anteriores, de los cuales se desconocen los informes de intervención. Pero también será importante la intervención en otros espacios, a saber, torres de vigilancia y ciudades altas, que pueden haber sido antiguos espacios centrales. En cualquier caso, el acercamiento a estos sitios y contextos materiales debe ser cauteloso y libre de prejuicios, ya que la materialización del poder de las posibles élites locales debe transformarse de manera que difiera de otros territorios no periféricos. Es decir, hay que intentar encontrar los marcadores de caracterización arqueológica de estas élites en cada territorio, y no a través de meras comparaciones con los elementos utilizados en otras regiones.

También en este primer objetivo principal se encuentra la premisa de la evolución / transición / mutación de la red de hábitats rurales alto medieval a la red poblacional que en los siglos XII y XIII está bien expresada en la documentación. En este punto, los datos aún son escasos para que podamos entender el proceso. Existe una tendencia a percibir una diferenciación espacial, organizativa y operativa entre estos dos mundos. Sin embargo, la visión actual puede estar sesgada por la falta de datos arqueológicos, que nos permitan comprender cuándo ocurrió la despoblación de algunos sitios de la alta Edad Media, la génesis de los sitios a los que se hace referencia en los documentos y la posibilidad de un predominio de espacios ocupados en una larga diacronía. Estas preguntas también llevan a la necesidad de desarrollar una futura línea de investigación específica. Es decir, las intervenciones paralelas en yacimientos despoblados, en yacimientos documentados a mediados de la Edad Media, y actualmente habitados, $\mathrm{y}$ en yacimientos que presentan trazos medievales altos, se registran a mediados de la Edad Media, pero que están despoblados desde la época moderna o contemporánea. De esta forma, conociendo los tres contextos, especialmente su componente material, también puede ser posible identificar otros espacios con las mismas cronologías, principalmente en el trabajo de prospección. 
Asimismo, y siguiendo lo mencionado en el párrafo anterior, la intervención arqueológica en los pueblos fortificados puede inferir datos sobre el mismo problema de evolución / transición / mutación y sobre todo su génesis. Por otro lado, permitirá comprender las interacciones entre diferentes espacios, comunidades y entre amos y campesinos, es decir, la articulación del territorio a escala local y regional.

Las últimas consideraciones referentes al primer objetivo enumerado ya se refieren al período medieval completo. La estructura de la población, modelos, sistemas, agentes y masa humana nos son muy notorios a través de datos documentales. Sin embargo, a pesar de que la historiografía ha tenido un gran interés y desarrollo durante este período y territorio, somos conscientes de que aún queda trabajo por hacer. En concreto, nos referimos a la transcripción, estudio paleográfico y diplomático de documentos que pueden aportarnos nuevos datos, interpretaciones, o que corroboran o refutan ideas e hipótesis, pero principalmente que nos permiten comprender la veracidad o falsedad de determinados documentos. Esta premisa es fundamental, sobre todo teniendo en cuenta que en nuestro caso se trata de un área temática complementaria, y en la que no tenemos los conocimientos para suprimirla individualmente. Por tanto, consideramos que también estamos ante una línea de investigación futura que no debe pasarse por alto, pero que permanece abierta a otros investigadores con competencias específicas en estas materias.

A los datos históricos recopilados, agregamos los datos arqueológicos existentes resultantes de esta investigación. No porque pensemos que la Arqueología medieval no es una disciplina independiente y susceptible de ser realizada de forma autónoma, sino porque para el territorio en estudio solo la combinación de las dos disciplinas permitiría un discurso más uniforme ante la falta de datos existentes en cada una de ellas. . Este emparejamiento de datos es particularmente relevante en lo que respecta a la estructura de asentamiento y las estrategias de organización territorial o administrativa. En cuanto a los datos arqueológicos, se debe evidenciar su potencialidad para la caracterización de la vida cotidiana de las poblaciones y destacar los estratos de la sociedad menos visibles a través de la documentación. Sin embargo, los datos arqueológicos no están exentos de críticas. Por un lado, se hizo evidente la desigualdad de datos entre el mundo urbano y rural, e incluso entre los diferentes espacios de intervención. Por otro lado, es obvio que los datos sobre la propia cultura material están en su génesis, o incluso estancados, focalizando su estudio a través de comparaciones estilísticas con materiales y sitios tan lejanos como Santa Cruz de Vilariça. Este escenario es bastante evidente cuando un 
conjunto de cerámica está fechado en gran parte como medieval, y puede corresponder a principios del siglo XII o finales del siglo XIV. Fruto de este escenario, consideramos importante continuar una línea de investigación sobre la evolución crono-tipológica de la cerámica, que debe sustentarse a través del cruce de contextos seguros y fechas absolutas de esos mismos contextos de procedencia. A estos hay que sumar una caracterización estilística y tecnológica completa de las colecciones materiales identificadas, solo así será posible determinar diferenciaciones tecno-tipológicas y trazar un marco de referencia para el territorio.

En cualquier caso, se debate lo que vimos durante esta investigación: la presencia de un espacio periférico y la necesidad de su abordaje epistemológico diferenciado. La ausencia de poderes centrales, o su influencia directa, en este espacio, asignaría así la posibilidad de una mayor diversidad de formas de organización social. Es decir, no habría una estandarización de tipologías de hábitat, relaciones socioeconómicas y formas de explotación territorial, propias de sistemas y estados muy centralizados, como el Imperio Romano o los reinos peninsulares a partir de la Baja Edad Media. Sin embargo, esta es una vista basada en una escala supralocal. Este espacio periférico mantendrá su poder y núcleos jerárquicos en el nivel local y, en consecuencia, las relaciones centro-periferia a su escala. En esta coyuntura, por lo tanto, será necesario encontrar primero estas relaciones a escala local, es decir, en micro territorios, y solo más tarde intentan un abordaje a escala supralocal. Más aún para comprender no solo las relaciones jerárquicas sino para tratar de comprender la tipología de "bienes de consumo" de bajo valor que esta región brindaría a los centros (locales y supralocales).

De las líneas expuestas anteriormente, se desprende que el objetivo planteado no fue del todo posible de alcanzar, y que existen principalmente cuestiones nuevas derivadas de la propia investigación.

Por otro lado, en relación al segundo gran objetivo (Côa como frontera) tendemos a considerar que el estado de conocimiento y los argumentos planteados permiten una realización casi total. En nuestra opinión, la idea de Ribacôa de la dominación portuguesa, antes de su incorporación al reino leonés, resulta de una línea cronológica portuguesa, naturalmente facciosa, para legitimar su posesión por D. Dinis. Esta sería, con el tiempo, perpetuada por la historiografía portuguesa, de carácter nacionalista, para exaltar la hazaña trascendental que supuso la expansión del pequeño reino portugués a expensas del vecino reino de Castilla y León. Sin embargo, es en este 
espectro temporal donde debe entender la génesis del Côa como una frontera, es decir, entre mediados del siglo XII y mediados del siglo siguiente. Pero, de nuevo, no necesariamente cumpliendo con lo que la historiografía portuguesa ha ido exacerbando. Para la citada línea historiográfica se había producido una clara imposición de dos líneas de fortificaciones opuestas y antagónicas, por parte de los dos reinos, creando una frontera altamente militarizada, idea que refutamos. Se trataría ante un proceso de incorporación de territorios bajo la égida de las dos monarquías, recurriendo a poderes, ya sean eclesiásticos, pero sobre todo seculares, establecidos localmente en épocas anteriores. Estos poderes seculares acaban convirtiéndose en agentes reales mediante la creación de verdaderos consejos.

En definitiva, tras estas líneas, más que consideraciones finales, nunca dogmáticas, se pretendía enunciar posibles líneas futuras de investigación. Más que nada, se deseaba contribuir al conocimiento histórico de una región periférica secular, que sólo ocasionalmente, y por cuestiones fronterizas, tenía en la época medieval (como en nuestros días) algún interés para los poderes centrales. Sin embargo, nunca hay un movimiento o acercamiento de los centros a este territorio. 


\section{Bibliografia}

AA.VV. (1998a): O Tratado de Alcanices e a importância histórica das terras de RibaCôa. Lisboa: Universidade Católica Editora.

AA.VV. (1998b): História: Revista da Faculdade de Letras, Porto: Faculdade de Letras Universidade do Porto, Vol. 15, n.1.

ABREU, C., HERNÁNDEZ, R. (2014): "O Castelo de Monforte de Ribacôa - primeiras impressões arqueográficas de uma fortificação medieval leonesa", Sabucale - Revista do Museu do Sabugal, 6: 101-118.

ALARCÃO, J. de (1995): "Aglomerados urbanos secundários romanos de entre Douro e Minho", Biblos, 71: 387-401.

ALARCÃO, J. de (1997): “A tecnologia agrária romana”, in ALARCÃO, A. (ed): Portugal romano. A exploração dos recursos naturais: 137-148. Lisboa: Museu Nacional de Arqueologia.

ALARCÃO, J. de (1998): "A paisagem rural romana e altomedieval em Portugal", Conimbriga, 37: 89-119. ALARCÃO, J. de (1999): "Os arredores das cidades romanas de Portugal", Archivo Español de Arqueologia, 72: 31-37.

ALARCÃO, J. de (2000): "As paróquias suévicas do território actualmente português", Separata de Religión, Lengua y Cultura prerromanas da Hispania. Salamanca: Universidad de Salamanca, 29-59.

ALBUQUERQUE, E. (2005): Entre sigillata e faiança: primeiro estudo sobre a cerâmica de Torre de Almofala. Coimbra. Tese de Mestrado em Arqueologia apresentada Faculdade de Letras Universidade de Coimbra. Policopiado.

AlBUQuerque, E., CARVAlho, S., SOUSA, A. (2008): "Torre de Almofala: materiais de superfície", Praça Velha, 24: 204-226.

ALBUQUERQUE, P. (2014): Tartessos: a construção de identidades através do registo escrito e da documentação arqueológica. Um estudo comparativo. Tese de Doutoramento em arqueologia apresentada á Faculdade de Letras da Universidade de Lisboa. Policopiado.

ALBUQUERQUE, P., GARCÍA FERNÁNDEZ, F. (2015): "Sobre o conceito de Fronteira: o Guadiana numa perspectiva arqueológica", Anejos de AespA, LXXX: 175182.

ALBUQUERQUE, P. (2017): "O Guadiana como fronteira? Notas para um projecto de investigação", Ophiussa, 1: 69-78. 
ALBUQUERQUE, P., GARCÍA FERNÁNDEZ, F., PALMA, M., GRADIM, A. (2020): ¿¿Frontera acuática o frontera líquida? El Bajo Guadiana en la Antigüedad". In GASPAR, C., GIMENO PASCUAL, H., VICENT RAMÍREZ, N. (coord.): Ambientes epigráficos y territorio: el Guadiana entre Bética y Lusitania: 63-92. Lisboa: Centro de Estudos Clássicos - Fundación General Universidad de Alcalá.

ALMEIDA, J. (1945): Roteiro dos Monumentos Militares Portugueses. Lisboa: Império.

ALMEIDA, M. J. (1992): Foral e Foros da Guarda. Edição e Estudos Linguísticos do Documento Manuscrito Português. Provas de Aptidão Pedagógica. Viseu: Centro de Viseu da Universidade Católica Portuguesa.

AMARAL, L. (1994): São Salvador de Grijó na segunda metade do séc. XIV. Estudo de gestão agrária. Lisboa: Edições Cosmos.

ACIÉN ALMANSA, M. (1989): "Poblamiento y fortificación en el sur de al-Ándalus. La formación de un país de ḥuṣūn", Actas del III Congreso de Arqueología Medieval Española. Ponencias, 1: 135-150.

ACIÉN ALMANSA, M. (1992): "Sobre la función de los ḥuṣūn en el sur de al-Ándalus. La fortificación en el califato", Coloquio Hispano-Italiano de Arqueología Medieval, Granada: 263-270.

ACIÉN ALMANSA, M. (2006): "Las torres/burūŷ en el poblamiento andalusí”, AlÁndalus, espaço de mudança. Balanço de 25 anos de história e arqueología medievais: 21-28.

ACIÉN ALMANSA, M. (2008): "Un posible origen de la torre residencial en alÁndalus”. In MARTÍ CASTELLÓ, R. (ed.): Fars de l'Islam. Antigues alimares d'alÁndalus: 57-88, Barcelona.

AMARAL, L., \& GARCIA, J. (1998): "O Tratado de Alcañices (1297): uma construção historiográfica", Revista da Faculdade de Letras: História, 15: 967-986.

ARAÚJO, J. N. (2013): A cerâmica islâmica do castelo de Palmela: análise tipológica e crono-estratigráfica dos materiais da galeria 5. Tese de Mestrado em Arqueologia apresentada Faculdade de Letras Universidade de Lisboa. Policopiado.

ARINO GIL, E. (2013): "El hábitat rural en la Península Ibérica entre finales del siglo IV y principios del VIII: un ensayo interpretativo", Antiquité Tardive, 21: 93-123

ARIÑO GIL, E., DÍAZ, P. (2014): La Frontera Suevo-Visigoda. Ensayo le lectura de un territorio en disputa. In CATALÁN, R., FUENTES, P., SASTRE, J. C. (eds.): 
Fortificaciones en la Tardoantigüedad: Élites y articulación del territorio (Siglos V-VIII d. C.): 179-190, Madrid.

AZEVEDO, P. (1910): "Documentos de Santa Maria de Aguiar (Castello Rodrigo)", Revista Lusitana, XIII: 1-17.

AZEVEDO, P. (1913): "Dois Documentos de Riba-Côa da época leonesa", Revista de História, II: 184-186.

AZEVEDO, R. (1935): "Fronteira entre Portugal e Leão em Riba-Côa, antes do Tratado de Alcanices (1297)". Separata Biblos, 10; 9-12: 454-466.

AZEVEDO, R. de (1962): "Riba Coa sob o domínio de Portugal no reinado de D. Afonso Henriques. O mosteiro de Santa Maria de Aguiar, de fundação portuguesa e não leonesa". Anais da Academia Portuguesa da História, II série, vol. 12: 231-298.

BAQUERO MORENO, H. (1998): "O tratado de Alcanices à Luz da Diplomacia". O Tratado de Alcanices e a Importância Histórica das terras de Riba Côa. Lisboa: Universidade Católica Editora. 41-52.

BAQUERO MORENO, H. (2003): Demarcações de fronteiras. De Vila Velha de Ródão a Castelo Rodrigo. Porto: Centro de Investigação e Documentação de História Medieval da Universidade Portucalense - Infante D. Henrique.

BARBOSA, P. (1998): "Organização defensiva na fronteira beirã oriental: "Extremadura" e Riba Côa até ao século XIII", Revista da Faculdade de Letras do Porto - História, XV:1: 199-212.

BARRIOS, A. (1998): "El proceso de ocupación y de ordenación del espacio en la raya leonesa", O Tratado de Alcanices e a importancia histórica das terras de Riba Côa, 155183.

BARRIOS, A. (2002): "En torno a los orígenes y la consolidación de la diócesis civitatense", Actas del Congreso de Historia de la Diócesis de Ciudad Rodrigo, vol. I: 169-210.

BARRIOS, A., MONSALVO, J.M., SER, G. del (1988): Documentación medieval del archivo municipal de Ciudad Rodrigo. Salamanca: Ediciones de la Diputación de Salamanca.

BARROCA, M. (1987): Necrópoles Sepulturas Medievais de Entre Douro e Minho (séculos $\mathrm{V}$ a XV). Trabalho apresentado no âmbito das provas públicas de aptidão pedagógica e capacidade científica, na Faculdade de Letras da Universidade do Porto. Policopiado. 
BARROCA, M. (1990): “Contribuição para o estudo dos testemunhos pré-românicos de Entre-Douro-e-Minho", Actas do Congresso Internacional do IX Centenário da Dedicação da Sé de Braga, IV: 101-145.

BARROCA, M. (1991): "Do Castelo da Reconquista ao Castelo Românico (Séc. IX a XII", Portvgalia, Nova Série, XI-XII: 89-136.

BARROCA, M. (1997): "A Ordem do Templo e a Arquitectura Militar Portuguesa do Século XII”, Portugalia Nova Série, XVII-XVIII: 171-209.

BARROCA, M. (1998a): "D. Dinis e a Arquitectura Militar Portuguesa", Actas das IV Jornadas Luso-Espanholas de História Medieval, I: 801-822.

BARROCA, M. (1998b): "Torres, Casas-Torres ou Casas-Fortes. A Concepção do Espaço de Habitação da Pequena e Média Nobreza na Baixa Idade Média (Sécs. XIIXV)". Revista de História das Ideias, 19: 39-103.

BARROCA, M. (2000): "Aspectos da evolução da arquitectura militar da Beira Interior", Beira Interior História e Património, 215-238.

BARROCA, M. (2001): "Aron de Castelo Mendo", Estudos em Homenagem a João Francisco Marques, 1: 183-197.

BARROCA, M. (2003): "Da Reconquista a D. Dinis". In MATTOSO, J. (coord.): Nova História Militar de Portugal: 20-161. Lisboa: Círculo de Leitores.

BARROCA, M. (2008-2009): "De Miranda do Douro ao Sabugal - Arquitectura militar e testemunhos arqueológicos medievais num espaço de fronteira", Portugália, Nova Série, XXIX-XXX: 193-252.

BARROCA, M. (2010/2011): "Sepulturas escavadas na rocha de Entre Douro e Minho", Portugália, Nova Série, XXX-XXXII: 115-182.

BARROS, L. (2005): Monografia de Almofala. Figueira de Castelo Rodrigo. Município de Figueira de Castelo Rodrigo.

BARTLETT, R., MACKAY, A. (1989): Medieval Frontier Societies. Oxford.

BEREND, N. (1999): "Medievalists and the notion of frontier", The Medieval History Journal, 2:1: 55-72.

BOlila, C., ROMÃO, J., MATOS, S., PEREIRA, S., PRATA, S., PEREIRA, T., TENTE, C. (2013): "O Castro do Jarmelo (Guarda). Estudos dos materiais arqueológicos recolhidos na intervenção de emergência de 1998". In FERNANDES, I. (ed.): Fortificações e território na Península Ibérica e no Magreb (Séculos VI a XVI): 829-836. Palmela: Colibri/Campo Arqueológico de Mértola. 
BOISSELLIER, S. (2012): La construction administrative d'un royaume. Registres de bénéfices ecclésiastiques portugais (XIII-XIVe siècles). História Religiosa - Fontes e Subsídios, Lisboa: Centro de Estudos de História Religiosa - UCP.

BORGES, J. (1997): O Mosteiro de Santa Maria de Aguiar e os Monges de Cister. Figueira de Castelo Rodrigo: Câmara Municipal de Figueira de Castelo Rodrigo.

BRANCO, M. (2006): D. Sancho I. Lisboa: Círculo de Leitores.

BRANDÃO, A. (1690): Terceira parte da monarchia lusytana: que contém a historia de portugal, desde o conde dom henrique, até todo o reynado d"el rey dom afonso henriques. Lisboa: Impressão Craesbeeckiana.

BRAUDEL, F. (1958): Histoire et sciences sociales: la longue durée. 4: 725-753.

BRITO, B. (1602): Primeira parte da Crónica de Císter, onde se contâo as couas principias desta orden e muitas antigüedades do Reino de Portugal como de outros muytos da christandade. Lisboa: por Pedro Crasbeek, 1602. - [5], 494.

BRITO, B. (1690a): Monarchia Lusytana / composta por Frey Bernardo de Brito. Parte primeira que contém as historias de portugal, desde a criaçaõ do mundo até o nascimento de nosso senhor jesu christo. lisboa: impressão craesbeeckiana.

BRITO, B. (1690b): Segunda parte da monarchia lusytana : em que se continuaõ as historias de portugal, desde o nascimento de nosso salvador jesu christo, até ser dado em dote ao conde dom henrique. Lisboa: Impressão Craesbeeckiana.

BROKES, S., TENTE, C., PRATA, C. (2017): "Interpreting Rock-Cut Grave Cemeteries: The Early Medieval Necropolis and Enclosure of São Gens, Portugal", Medieval Archaeology, 61:2: 215-238.

BURESI, P. (2009): "Pour une méthodologie de l'étude de la frontière entre chrétienté et Islam. La péninsule Ibérique xie-xiiie siècles". In SABATÉ, F. (ed.): Arqueologia Medieval. La transformació de la frontera medieval musulmana, II: 81-92.

CABALLERO ZOREDA, L. (1994): "Un canal de transmissión de lo clásico a la Alta Edad Media española. Arquitectura y escultura de influjo omeya en la Península Ibérica entre el siglo VII y inícios del siglo X", Al-Qantara, CSIC, XV: 321-348.

CABRAL, A. (1965): "A Torre de Aguiar ou "Turris Aquilaris"", Beira Alta, 24 (4): 425-432.

CALONGE, A. (2020): "El mantenimiento del entramado viario romano en época medieval en La Rioja. Algunos casos de estudio". Espacio Tiempo y Forma. Serie III, Historia Medieval, 33: 43-68. 
CAETANO, C. (2011): As Casas da Câmara dos concelhos portugueses e a monumentalização do poder local: (séculos XIV a XVIII). Tese doutoramento em História apresentada à Faculdade de Ciências Sociais e Humanas da Universidade Nova de Lisboa. Policopiado.

CAPELA, J., MATOS, H. (2013): "As freguesias do distrito da Guarda nas Memórias Paroquiais de 1758: Memórias, História e Património". In CAPELA, J. (ed.): Portugal nas Memórias Paroquiais de 1758: 8. Braga: Universidade do Minho.

CAMEIJO, A. (2013): Projecto R. Requalificação Paisagística e Patrimonial Muralha Poente, Guarda. Relatório de Progresso. Policopiado.

CAMEIJO, A., PEREIRA, V. (2008): "A Necrópole do Largo das Freiras (Sé, Guarda). Notícia Preliminar", Praça Velha, 1série, 29: 223-234.

CAMEIJO, A., PEREIRA, V. (no prelo) - Requalificação e Musealização do Primitivo Castelo Medieval da Guarda, Guarda. Relatório Final de Trabalhos Arqueológicos. Policopiado.

CARANDINI, A. (1981): Storie dalla terra. Manuale di scavo. Torino.

CARVAlHEIRA, A. M. (2002): A Igreja Cisterciense de Santa Maria de Aguiar. O conjunto arquitectónico medieval e as campanhas de restauro da DGEMN (1936-1962). Vila Nova de Foz Côa: Parque Arqueológico Vale do Côa e IPA-Instituto Português de Arqueologia.

CARVALHO, P. (2006): Cova da Beira. Ocupação e exploração do território na época romana. Tese de Doutoramento em Arqueologia apresentada à Faculdade de Letras da Uniersidade de Coimbra. Policopiado.

CARVALHO, P. (2010) - "A caminho do Douro na época romana: da capital da civitas Igaeditanorum aos territoria dos Lancienses, Araui, Meidubrigenses e Cobelci”. In CUBAS MARTÍN, N., HIDALGO RODRÍGUEZ, D., SALINAS DE FRÍAS, M. (ed.), Arqueología, Patrimonio, Prehistoria e Historia Antigua de los pueblos 'sin passado': ecos de la Lusitania en Arribes del Duero: 125-138. Salamanca: Aquilafuente 171.

CARVAlHOSA, A. (1959): Carta Geológica de Portugal. Nota explicativa da Folha 15-D Figueira de Castelo Rodrigo. Lisboa: Serviços Geológicos de Portugal.

CASTAÑO AGUILAR, J. M. (2016): "El final de la villa y la continuidad del poblamiento: un debate entre turres y ḥuṣūn. El caso de la Serranía de Ronda", Mainake,XXXVI: 111-136.

CASTAÑO AGUILAR, J. M. (2019): ¿Torres sin alquerías? De nuevo sobre el origen de la torre residencial en Al-Ándalus", Arqueología y Territorio Medieval, 26: 7-30. 
CASTELLANOS, S., MARTÍN VISO, I. (2005): "The local articulation of central power in the north of the Iberian Peninsula (500-1000)". Early Medieval Europe, 13: 142.

CASTILLO, A. (1970): "Cronología de las tumbas llamadas olerdolanas", XI Congreso Nacional de Arqueología, 835-845.

CASTRO, A. (2013): "A paisagem monástica no Vale do Varosa o caso dos Mosteiros Cistercienses de St. ${ }^{a}$ Maria de Salzedas e S. João de Tarouca", CEM Cultura, Espaço \& Memória: Revista do CITCEM, 4:25-49.

CASTRO, J. (1902): Diocese e districto da Guarda. Porto: Typ. Universal (a Vapor).

CORTÉS, J., CASTRO, A., COBOS, A. (2001) - Guía de la ruta de las fortificaciones de frontera Salamanca. Valladolid: Fundación Del Patrimonio Histórico De Castilla Y León.

CASTRO MARTíNEZ, P., GONZÁLEZ MARCÉN, P. (1989): "El concepto de frontera: implicaciones teóricas de la noción de territorio político", Arqueología Espacial, 13: 7-18.

CHORÃO, M. J. (2002): Memórias Paroquiais. Guarda: Câmara Municipal da Guarda.

CINTRA, L. (1959): A Linguagem dos Foros de Castelo Rodrigo: seu confronto com a dos foros de Alfaiates, Castelo Bom, Castelo Melhor, Cória, Cáceres e Usagre: Contribuição para o estudo do Leonês e do Galego-Português do século XIII. Lisboa: Livraria Sá da Costa.

COBOS, F. (2016): "O Sistema de Forti $\neg$ caçao Fronteiriço do antigo Reino de Leão frente a Portugal e Castela (1161-1230)", CEAMA, 13: 36-84.

COELHO, M. H. (1989): O Baixo Mondego nos finais da Idade Média. Lisboa: Casa da Moeda.

COELHO, M. H., MORUJÃO, M. (1999): Forais e Foros da Guarda. Guarda: Câmara Municipal da Guarda.

COELHO, M. H., RÊPAS, L. (2006): "Um cruzamento de fronteiras. O discurso dos Concelhos da Guarda em Cortes", Iberografias, 9: 1-220.

COHEN, A. (1969): "Political Anthropology: The analysis of the symbolism of power relations", Man, 8(2): 215-255.

COIXÃO, A. (2017): A romanização no Baixo Côa. Vila Nova de Foz Côa: Câmara Municipal de Vila Nova de Foz Côa.

CONCEIÇÃO, M. T. (2002): Da vila cercada à praça de guerra: formação do espaço urbano em Almeida, séculos XVI-XVIII. Lisboa: Livros Horizonte. 
CORRAL VAL, L. (1999): Los monjes soldados de la Orden de Alcántara en la Edad Media su organización institucional y vida religiosa. Madrid: Castellum.

CORRAL VAL, L. (2012): "La dimensión religiosa de la orden del Pereiro-Alcántara en la Edad Media". In FERNANDES, I. C. (coor.): As Ordens Militares. Freires, Guerreiros, Cavaleiros. Actas do VI Encontro sobre Ordenes Militares,.I: 243-264.

COSME, S. (2002): Entre o Côa e o Águeda: povoamento nas épocas romana e Alto medieval. Tese de Mestrado em Arqueologia defendida na Faculdade de Letras da Universidade do Porto. Policopiado.

COSTA, A. (1708): Corografia portugueza e descripçam topografica do famoso Reyno de Portugal, com as noticias das fundações das cidades, villas, \& lugares, que contem; varões illustres, gealogias das familias nobres, fundações de conventos, catalogos dos Bispos, antiguidades, maravilhas da natureza, edificios, \& outras curiosas observaçoens. Tomo II. Lisboa: officina de Valentim da Costa Deslandes.

COSTA, A. D. (1963): Mestre Silvestre E Mestre Vicente, JuristaS dA Contenda entre D. Afonso II e Suas Irmãs. Braga: Franciscana.

COSTA, A., MARQUES, M. (1989): "Bulário Português Inocêncio III (1198-1216)", Série História 7, Coimbra Imprensa de Coimbra.

COSTA, M. (1977): História do Bispado e Cidade de Lamego. Lamego: Braga Of. Gráf. Barbosa \& Xavier.

COSTA, P. (1993): A Ordem Militar do Hospital em Portugal: Séculos XII-XIV. Tese de Mestrado em História apresentada à Faculdade de Letras da Universidade do Porto. Policopiado.

COSTA, P. (2010): Os Forais de Pinhel. Pinhel: Câmara Municipal de Pinhel.

CUESTA-GÓMEZ, J. F., PRATA, S., RAMOS, T. (2018): Empezar la casa por el tejado: las cerámicas de cobertura en los contextos altomedievales del territorio de Castelo de Vide (Portugal). In MARTIN VISO, I., FUENTES MELGAR, P., SASTRE BLANCO, J. C., CATALÁN RAMOS, R. (eds.): Cerámicas Altomedievales en Hispania y su entorno (Siglos V-VIII d.C.): 137-158. Valladolid: Glyphos.

CUNHA, E., UMBELINO, C., TAVARES, T. (2001): "A Necrópole de São Pe $\neg$ dro de Marialva. Dados antropológicos". Património/Estudos, 1:139-143.

CURADO, F. (1982): “A viação romana no concelho de Penamacor. Contribuição para o estudo da via de Mérida a Braga", Actas e Memórias do 1. Colóquio de Arqueologia e História do Concelho de Penamacor, 82-98. 
CURADO, F. (1988-1994): “A propósito de Conimbriga e de Coniumbriga”, Gaya Actas do $1^{\circ}$ Congresso Internacional sobre o Rio Douro, 6: 213-234.

CURADO, F. (2004): “A Martim Calvo e aos povoadores do Fundão”, Eburobriga, 2: 77-115.

CURADO, F. (2013): "Notas sobre dois marcos miliários prismáticos, de Augusto (23 a. C.)", Sabucale, 5: 59-74.

DE KOE, T., SEQUEIRA, M. M., BENTO, J., ARANHA, J. T., VAREJÃO, E. (1997): Habitats naturais e de espécies da flora de Portugal (Continente). Oeste de Trás-osMontes, Alto Douro e Norte da Beira Alta: Douro Internacional. Relatório Final. Vila Real: Universidade de Trás-os-Montes e Alto Douro. Policopiado.

TORRE RODRÍGUEZ, J. (1996): "A Comarca de Ribacôa no Tratado de Alcañices", Douro - Estudos \& Documentos, 1:1: 15-25.

DE MAN, A., CORREIA, V., LOVEGROVE, S., ANDRADE, F. (2004): "Cerâmica Medieval e Conimbriga". In DE MAN, A., TENTE, C. (coor.): Estudos de Cerâmica Medieval O Norte e Centro de Portugal - Séculos XI a XII. IEM. Coleção ESTUDOS. 7: $57-67$.

DIAS, J. J. (2004): Chancelarias portuguesas: D. João I. Vol. 1, 2, 3. Lisboa: Centro de Estudos Históricos da Universidade Nova de Lisboa.

DÍEZ HERRERA, C. (2006): "Sociedad de frontera y monasterios familiares en la meseta del Duero en el siglo X". In GARCÍA DE CORTÁZAR, J. A., TEJA, R. (coord.): Monjes y monasterios hispanos en la Alta Edad Media: 35-57. Aguilar de Campóo: Fundación Santa María la Real.

ESCALONA, J. (2014): "Épica y Falsificaciones Documentales en la Castilla Medieval". In VELÁZQUEZ, I., MARTÍNEZ, J. (ed.): Realidad, ficción y autenticidad en el Mundo Antiguo: La investigación ante documentos sospechosos: 223-242.

FABIÃO, C. (2009): "O Ocidente da Península Ibérica no século VI: sobre um pentanummium de Justiniano I encontrado na unidade de produção de preparados de peixe da Casa do Governador da Torre de Belém", Apontamentos de Arqueologia e Património, 4: 25-50.

FÁBREGA-ÁlVAREZ, P. e PARCERO-OUBIÑA, C. (2019): "Now you see me. An assessment of the visual recognition and control of individuals in archaeological landscapes.” Journal of Archaeological Science. 104 p.56-74. 
FARELO, M. (2016): " Do processo de refundação da diocese a 1505". In PAIVA, J. P. (coord.): História da Diocese de Viseu. Vol. 1 [séc. VI a 1505]: 446-496. Viseu: Diocese de Viseu e Imprensa da Universidade de Coimbra.

FEBVRE, L. (1962): "Frontière: le mot et la notion". In FEBVRE, L. (ed.): Pour une histoire à part entière: 11-24. Paris: SEVPEN.

FERNANDES, A. (1971): "Portugal no Período Vimaranense (868-1128)", Revista de Guimarães, 81 (1-2): 51-98.

FERNANDES, A. (1976): "Acção dos Cistercienses de Tarouca. As granjas nos séculos. XII e XIII", Revista Guimarães, IV ${ }^{\text {a }}$ Parte, 86: 5-123.

FERNANDES, A. (1991): Taraucae Monumenta Historica: Livro das Doações de Tarouca. Vol 1-3. Tarouca : Câmara Municipal de Tarouca.

FERNADES, A. (1993): Taraucae Monumenta Historica. Indices \& Studia. Braga: Câmara Municipal de Tarouca.

FERNANDES, H. (2006): D. Sancho II: tragédia. Lisboa: Círculo de Leitores.

FERNANDES, L. (1999): "Novos elementos sobre a cidade da Guarda - séculos XIII ao XVII". Separata da Praça Velha. Guarda: Câmara Municipal da Guarda.

FERNANDES, L. (2000): "Novos elementos sobre o castelo da Guarda (séculos XIIIXVIII)". In FERREIRA, M. (ed.): Actas das I.as Jornadas de Património da Beira Interior: 239-252. Guarda: Câmara Municipal da Guarda.

FERNANDES, L., CARVALHO, E., JULIÃO, T. (1999): "A Alcáçova da cidade da Guarda - proposta de reconstituição", Arqueologia Medieval, 6: 59-72.

FERNANDES, L, MARQUES, A., TORRES, A. (2008): "Ocupação baixo medieval do teatro romano de Lisboa: a propósito de uma estrutura hidráulica cerâmicas vidradas e esmaltadas", Arqueologia Medieval, 10: 159 - 183.

FERNANDES, P. (2008): “A Igreja de São Pedro de Lourosa e a sua relação com a arte asturiana", Arqueologia Medieval, 10: 21-40.

FERNANDES, P. (2016a): Matéria das Astúrias. Ritmos e realização da expansão asturiano-leonesa no actual centro de Portugal séculos VIII-X. Tese de Doutoramento em História da Arte apresentada à Faculdade de Letras da Universidade de Lisboa. Policopiado.

FERNANDES, P. (2016b) - "Românico da Diocese de Viseu". In PAIVA, J. P. (coord.): História da Diocese de Viseu. Vol 1 [séc. VI a 1505]: 84-96. Viseu: Diocese de Viseu e Imprensa da Universidade de Coimbra. 
FERNANDES, M. (2009): A ordem do Templo em Portugal (das origens à extinção). Tese de Doutoramento em História apresentada à Faculdade de Letras da Universidade do Porto. Policopiado.

FERNÁNDEZ CONDE, F. J. (1994): "La fundación de San Salvador de Valdediós. Fuentes epigráficas", La época de Alfonso III y San Salvador de Valdediós, Oviedo: Universidad de Oviedo, 213-247.

FERREIRA. A. (1978): Planaltos e montanhas do Norte da Beira. Estudo de Geomorfologia. Lisboa: Memórias do Centro de Estudos Geográficos, 4.

FIGUEIRA, N. (2018): Torre de Almofala [Almofala, Figueira de Castelo Rodrigo]. Sondagens arqueológicas de diagnóstico. Relatório Preliminar. Policopiado.

FITA, F. (1913): "Los premonstratenses en Ciudad Rodrigo. Datos inéditos", Boletín de la Real Academia de la Historia, 62: 468-480.

FONTE, A. (2016): Arqueologia, património e museus na Câmara Municipal de Almeida. Relatório de Estágio em Arqueologia apresentado na Faculdade de Ciências Sociais e Humanas da Universidade Nova de Lisboa. Policopiado.

FONTE, A. (2020): Inventário Arqueológico do Concelho de Almeida $1^{\text {a }}$ Fase. Relatório de Progresso 2019. Policopiado.

FRADE, H. (1990): Escavação e Valorização da Torre de Almofala - Figueira de Castelo Rodrigo. Relatório das Escavações arqueológicas de 1989. Policopiado.

FRADE, H. (1991): Escavação e Valorização da Torre de Almofala - Figueira de Castelo Rodrigo. Relatório das Escavações arqueológicas de 1990. Policopiado.

FRADE, H. (1992): Escavação e Valorização da Torre de Almofala - Figueira de Castelo Rodrigo. Relatório das Escavações arqueológicas de 1991. Policopiado.

FRADE, H. (1998): Escavação e Valorização da Torre de Almofala - Figueira de Castelo Rodrigo. Relatório das Escavações arqueológicas de 1997. Policopiado.

FRADE, H. (1999): Escavação e Valorização da Torre de Almofala - Figueira de Castelo Rodrigo. Relatório das Escavações arqueológicas de 1998. Policopiado.

FRADE, H. (1998): “Ara a Júpiter da Civitas Cobelcorum”, Ficheiro Epigráfico, 58 Doc 266.

FRANCISCO, J. M., NOVOA, F. (2014): El Reino de León y la orden del PereiroAlcántara (1168-1230), Medievalismo, 24: 79-109.

FRANCISCO, J. (2018): Côa, o rio que nos une: catálogo da exposição fotográfica de Jorge Abreu Vale. Carviçais: Lema d'Origem. 
FRANCISCO, J. P., GIL, T. (2016): "O projecto de investigação do Castelo de Monforte de Ribacôa como âncora de um amplo programa de Arqueologia Comunitária no Vale do Côa". In VILAÇA, R. (ed.): Actas do II Congresso Internacional de Arqueologia da Região de Castelo Branco: 413-428. Castelo Branco: Sociedade dos Amigos do Museu de Francisco Tavares Proença Júnior.

FEBVRE, L. (1962): "Frontière: le mote et la notion". In FEBVRE, L. (ed.): Pour une histoire à part entière: 11-24. Paris: École Pratique des Hautes Études.

FERNÁNDEZ MIER, M., QUIRÓS CASTILLO, J.A. (2018): "El aprovechamiento de los espacios comunales en el NW de la Península ibérica entra la romanidad y la Edad Media", Studies on the Value of Cultural Heritage, 18: 695-723.

FERNÁNDEZ MIER, M., FERNÁNDEZ FERNÁNDEZ, J., LÓPEZ GÓMEZ, P., RODRÍGUEZ PÉREZ, S. (2019): "Arqueología de las aldeas habitadas en Asturias: Los casos de Vigaña Arcéu y Villanueva de Santu Adrianu". Anejos de Nailos: Estudios interdisciplinares de arqueología, 5: 99-119.

FREIRE, A. (1916): "Tombo da Comarca da Beira (1395)", Archivo Historico Portuguez, X: 208-366.

GAIBROIS DE BALLESTEROS, M. (1922-28): Historia del reinado de Sancho IV de Castilla. Madrid: Tip. de la Revista de Archivos, Bibliotecas y Museos.

GARCIA ALONSO, M., MANTECÓN CALlEJO, L., MARCOS MARTÍNEZ, J. (2017): "La investigación arqueológica sobre caminos históricos en Cantabria. Aproximaciones a la metodología y la taxonomía", Sautuola: Revista del Instituto de Prehistoria y Arqueología Sautuola, XXII: 351-389.

GARCÍA DE CORTÁZAR, J. A. (2006): "Los monasterios del reino de León y Castilla a mediados del siglo XI un ejemplo de selección de las especies". In GARCÍA DE CORTÁZAR, J. A., TEJA, R. (coord.): Monjes y monasterios hispanos en la Alta Edad Media: 257-288. Aguilar de Campóo: Fundación Santa María la Real.

GARCIA MORENO, L. (1998): "Riba Coa en el periodo visigodo. O Tratado de Alcanices e a importância histórica das terras de Riba-Côa", Actas do Congresso Histórico Luso-Espanhol, 115-130.

GIL FERNANDÉZ, J., MORALEJO, J. L., RUIZ DE LA PEÑA, J. (1985): Crónicas asturianas: Cronica de Alfonso III (Rotense y “A Sebastián”), Crónica Albeldense (y "Profética"). Oviedo: Servicio de Publicaciones, Universidad de Oviedo, Departamento de Historia, Departamento de Historia Medieval. 
GIL-GARCÍA, M., ZAPATA, M., SANTISTEBAN, J., MEDIAVILLA, R., LÓPEZPAMO, E., DABRIO, C. (2007): "Late holocene environments. Las Tablas de Daimiel (south central Iberian peninsula, Spain)", Vegetation History and Archaeobotany, 16: 241-250.

GOMES, F. (2016): Contactos culturais e discursos identitários na I Idade do Ferro do Sul de Portugal (séculos VIII-V a.n.e.): leituras a partir do registo funerário. Tese de Doutoramento em Arqueologia apresentada à Faculdade de Letras da Universidade de Lisboa. Policopiado.

GOMES, J. (1981): História da diocese da Guarda. Braga: Pax distribuição.

GOMES, P. (1998): "Centros de Povoamento: um percurso pelas Vilas medievais". In LIMA, A. (ed.): Terras do CÔA: da Malcata ao Reboredo: os valores do Côa: 13-73. Guarda: Estrela-Côa.

GOMES, R. (1987): A Guarda medieval: posição, morfologia e sociedade (1200-1500). Lisboa: Livraria Sá da Costa.

GOMES, R. (1991): "A Construção das Fronteiras". In BETHENCOURT F., RAMADA, D. (ed.): A Memória da Nação: 357-382. Lisboa: Sá da Costa.

GOMES, R. (1994): Documentos para a história regional: Inventário da Igreja de Pousade, Revista Altitude (Nova Série), 1: 101-107.

GOMES, R. (1996): Castelos da Raia. I. Lisboa: IPPAR.

GOMES, P. (1998): “Centros de povoamento: um percurso pelas Vilas medievais", Terras do Côa, da Malcata ao Reboredo. Os valores do Côa, 59-63.

GÓMÉZ GANDULLO, J. (2006): “Avance sobre las excavaciones arqueológicas en elyacimiento de época visigoda de La Legoriza, San Martíndel Castañar (Salamanca)”, Zona arqueológica, 8 (1): 216-235.

Guerra, A. R. (2003): Os diplomas privados em Portugal dos séculos IX a XII: gestos e atitudes de rotina dos seus autores materiais. Lisboa: Centro de História da Universidade de Lisboa.

GONÇALVES, I. (1989): O património do mosteiro de Alcobaça nos séculos XIV e XV. Lisboa: Universidade Nova de Lisboa - Faculdade de Ciências Sociais e Humanas. GONÇALVES, I. (2009): " Povoamento medieval de Riba Coa". In GONÇALVES, I. (coord.): Paisagens rurais e urbanas. Fontes, metodologias, problemáticas. Actas das Quartas Jornadas: 53-107. Lisboa: Centro de Estudos Históricos da Universidade Nova de Lisboa. 
GONÇALVES, L. (1995): Os castelos da Beira interior na defesa de Portugal: século XII-XVI. Tese de Mestrado em História apresentada á Faculdade de Letras da Universidade de Lisboa. Policopiado.

GONÇALVES, F., GARCIA, I., NEVES, M. J. (2007): Largo de S. Martinho. Relatório Final dos Trabalhos de Arqueologia. Coimbra: Dryas Arqueologia, Lda. Policopiado.

GONZÁLEZ GONZÁLEZ, Julio (1960): El Reino de Castilla en la época de Alfonso VIII. Madrid: Escuela de Estudios Medievales. Vol. I-III.

GRAU MIRA, I. (2012): "Limite, confin, margen, frontera... conceptos y nociones en la Antigua Iberia". In PRADOS, F., GARCIA, I., BERNARD, G. (eds.): Confines: el Extremo del mundo durante la Antigüedad: 23-47.

GRAVE, J., ALMEIDA, M. (1924): Censual do Cabido da Sé do Porto: códice membranáceo existente na Biblioteca do Porto. Porto: Biblioteca Pública Municipal do Porto.

GUERRA, A. (2007): "Sobre o território e a sede dos Lancienses (Oppidani e Transcudani) e outras questões conexas", Conimbriga, 46: 161-206.

GUERRA, A. (2003): Os diplomas privados em Portugal dos séculos IX a XII: gestos e atitudes de rotina dos seus autores materiais. Lisboa: Universidade Centro de História. GUTIÉRREZ GONZÁLEZ, J. (2001): "Dominio político y territorio en la formación del feudalismo en el norte peninsular: Propuestas y reflexiones", V Congreso de Arqueología Medieval Española. Valladolid: Junta de Castilla y León, 629-656.

GUTIÉRREZ GONZÁLEZ, J. (2002): "La fortificación prefeudal en el norte peninsular: castros y recintos campesinos en la Alta Edad Media". In FERNANDES, I. (coord.): Mil Anos de Fortificações na Península Ibérica e no Magreb (500-1500), Actas do Simpósio Internacional sobre Castelos: 19-28.

GUTIÉRREZ GONZÁLEZ, J. (2011): "Fortificaciones visigodas y conquista islámica del norte hispano (c.711)", 711. Arqueologia e Historia entre dos mundos, 337-353.

GUTIÉRREZ GONZÁLEZ, J., BENÉITEZ GONZÁLEZ, C., LARRÉN IZQUIERDO, H. (1995): "Las pueblas fronterizas entre León y Portugal en los ss. XII y XIII: “ciudadelas" de Riba-Côa (Beira, Portugal)". In JORGE, V. (ed.): Actas 1. Congresso de Arqueologia Peninsular: 381-400. Porto: Sociedade Portuguesa de Antropologia e Etnologia.

GUTIÉRREZ LLORET, S. (2000): “Algunas consideraciones sobre la cultura material de las épocas visigoda y emiral en el territorio de Tudmir", Visigodos y Omeyas. Un 
debate entre la Antigüedad Tardía y la Alta Edad Media. Anejos de Archivo Español de Arqueología, XXIII: 95-116.

GUTIÉRREZ LLORET, S., SARABIA BAUTISTA, J. (2007): "El problema de la escultura decorativa visigoda en el sudeste a la luz del Tolmo de Minateda (Albacete): distribución, tipologías funcionales y talleres". In CABALLERO ZOREDA, L., MATEOS CRUZ, P. (eds.): Escultura decorativa tardorromana y altomedieval en la Península Ibérica: 299-341. Madrid: Consejo Superior de Investigaciones Científicas.

GONZALÉZ GONZALÉZ, J. (1943): Regesta de Fernando II. Madrid: Inst.Jeronimo Zurita. C.S.I.C.

GONZALÉZ GONZALÉZ, J. (1960): El Reino de Castilla en la época de Alfonso VII. Vol.1. Madrid: Escuela de Estudios Medievales.

HARRIS, E. (1989): Principles of Archaeological Stratigraphy. 2nd Edition. London: Academic Press.

HENRIQUES, I. (2004): Território e Identidade: a construção da Angola colonial (c. 1872-c. 1926). Lisboa: Centro de História Universidade de Lisboa.

HERCULANO, A. (1875): História de Portugal desde o começo da monarchia até ao fim do reinado de Affonso. III $8^{\mathrm{a}}$ Edição. Lisboa: Aillaud \& Bertrand.

HERNÁNDEZ SÁNCHEZ, F. (1993): Las rentas del Rey: sociedad y fisco en el reino castellano del siglo XIII. Monumenta Ecclesiae Toletanae historica. Serie IV, Registra. Madrid: Fundación Ramón Areces. Vol I-II.

HUNT, B. (2006): "The Medieval Warm Period, the Little Ice Age and simulated climatic variability", Climate Dynamics, 27: 677-694.

ISIDORO, P., DIAS, J., BASTOS, R. (2015): Côa (NE Portugal): o rio que une, aparta e protege! Em torno da definição do conceito de fronteira. In PEREIRA, S., RODRIGUES, M., BERGAMASCHI, S., FREITAS, J.G. (eds.): O Homem e as Zonas Costeiras: 157-167. Rede BrasPor.

JORGE, M. (2009): Geomorfometria da Bacia Hidrográfica do Rio Côa. Lisboa: IGOTUL.

JANECZEK, A. (2011): "Frontiers and Borderlands in Medieval Europe", Introductory Remarks, Quaestiones Medii Aevi Novae, 16: 5-14.

JUSTO SÁNCHEZ, D. (2018): "Castillos, Castros y Fortalezas durante la Expansión del Reino de León. Poder y Funciones en la Montaña Leonesa y el Interfluvio TávoraCôa (siglos X-XI0)", Studia Historica, Historia Medieval, 36(1): 31-56. 
KRISTIANSEN, K. (1987): Center and periphery in Bronze Age Scandinavia. In ROWLANDS, M. L., KRISTIANSEN, K. (eds.): Centre and Periphery in the Ancient World: 74-85. Cambridge: Cambridge University Press.

LADERO QUESADA, M. (1997): "La formación de la frontera de Portugal y el tratado de Alcañices (siglos XII y XIII)", Boletin de la Real Acaemia de la Historia, CXCIV, III: $425-458$.

LALIENA CORBERÁ, C., ORTEGA, J., BENAVENTE, J. (2007): Los problemas de escala y la escala de los problemas: algunas reflexiones sobre el poblamiento altomedieval en Bajo Aragón”. In SÉNAC, P. (ed): Villes et campagnes de Tarraconaise et d'Al-Andalus (VIE- XIE siècle: la transition): 249-262.

LAUWERS, M. (1996): La mémoire des ancêtres, le souci des morts. Morts, rites et société au Moyen Âge (Diocèse de Liège, XIe -XIIIe siècles). Paris: Beauchesne.

LAUWERS, M. (2010): "Circuit, cimetière, paroisse. Réflexions sur l'ancrage ecclésial des sites d'habitat (VIIe-XIIIe siècle)". In YANTE, J.-M., BULTOT-VERLEYSON, A.-M. (eds): Autour du "village". Établissements humaines, finages et communautés rurales entre Seine et Rhin (IVe -XIIIe siècles): 301-324. Louvain-La-Neuve.

LECANDA ESTEBAN, J.A., LORENZO JIMÉNEZ, J., DÍAZ DE GARAYO, E. P. (2008): "Faros y torres circulares: propuestas para el conocimiento de la efectividad del dominio islámico inicial en los territorios del alto Ebro", Fars de líslam, antigues alimares d'al-Andalus, 239-285.

LERNER, S. (1984): "Defining Prehistoric Frontiers: A methodological approach". In DE ATLEY, S., FINDLOW, F. (ed): Exploring the Limits. Frontiers and Boundaries in Prehistory: 51-66. Oxford: MacNeish.

LIBERATO, M. (2011): A cerâmica pintada a branco na Santarém Medieval. Uma abordagem diacrónica: séculos XI a XVI. Dissertação de mestrado em Arqueologia apresentada na Lisboa: Faculdade de Letras da Universidade de Lisboa. Policopiado.

LIBERATO, M., SANTOS, H. (2017): "O registo arqueológico de um centro urbano periférico do Médio Tejo: Torres Novas, séculos XII-XIV". In COSTA, A., ANDRADE, A., TENTE, C. (ed.): O papel das pequenas cidades na Construção da Europa medieval. 17: 197-212. Lisboa: IEM - Instituto de Estudos Medievais / Câmara Municipal de Castelo de Vide.

LIGHTFOOT, K., MARTINEZ, A. (1995): "Frontiers and Boundaries in Archaeological Perspective", Annual Review of Anthropology, 24: 471-492. 
LOBÃO, J., MARQUES, A., NEVES, D. (2005): "Povoamento romano na área da Torre de Almofala (civitas Cobelcorum)", Lusitanos e romanos no nordeste da Lusitânia. Jornadas de Património da Beira Interior. Guarda: Centro de Estudos Ibéricos. 171-189.

LOBÃO, J., FERREIRA, M. (2016): "Pontos no Mapa: notícia preliminar sobre a Carta Arqueológica de Trancoso". Al-Madan Online. II Série. 21. Tomo 1: 11-33.

LOMAX, D. (1963): "Las milicias Cistercienses en el reino de León", Hispania", XXI: $32-34$.

LOPES, I. (2002): Contextos materiais da morte durante a Idade Média: as necrópoles do Douro Superior. Tese de Mestrado em Arqueologia apresenta na Faculdade de Letras da Universidade do Porto. Policopiado.

LÓPEZ QUIROGA, J. (2010): Arqueología del mundo funerario en la Península Ibérica (siglos V-X). Madrid: La Ergástula, Ediciones.

LOURIE, E. (1966): "A society organised for war: Medieval Spain", Past and Present, 35: 54-76.

MAGALHÃES, J. (1996): "Fronteras y espacios Portugal y Castilla". In CARABIAS TORRES, A. (coord.): Las relaciones entre Portugal y Castilla en la época de los descubrimientos: 91-102.

MAGRO, M. (2011): Vilar Maior - Evolução de um castelo e povoado raiano de RibaCôa (Séc. XI a XV). Tese de Mestrado apresentada à Faculdade de Letras da Universidade do Porto. Policopiado.

MAIA, M. (1971a): Subsídios para a Carta Arqueológica de Figueira de Castelo Rodrigo. Lisboa: Dissertação de Licenciatura apresentada Universidade de Lisboa. Policopiado.

MAIA, M. (1971b) - "Arqueologia Romana no Ribacoa - O Templo romano de Almofala", Separata das Actas do II Congresso Nacional de Arqueologia, 471-477.

MANSILLA REOYO, D. (1965): La documentación pontificia de Honorio III: 1216 1227. Roma: Instituto español de estudois eclesiásticos.

MANTAS, V. G. (1992): “Teledetecção e vias romanas”, Jornadas sobre teledeteccion y geografia aplicadas a la arqueologia, Madrid, p. 165-174.

MANTAS, V. G. (2012): As vias romanas da Lusitânia, Mérida: Museo Nacional de Arte Romano. 
MARQUES, H. de (1984): Chancelarias Portuguesas: D. Pedro I, 1357-1367. Lisboa: Instituto Nacional de Investigação Científica\ Centro de Estudos Históricos da Universidade Nova de Lisboa.

MARQUES, A. (2008): O casal: uma unidade de organização social do espaço no Entre-Douro-e-Lima (906-1200). Noia (Corunha): Editorial Toxosoutos.

MARQUES, A. (2009): "Itinerários de uma unidade de organização social do espaço: o casal e o processo de senhorialização do Entre-Douro-e-Lima (906-1200)". In GONÇALVES, I. (coord.): Paisagens Rurais e Urbanas. Fontes, Metodologias, Problemáticas. Povoamento e População: 166-207. IV. Lisboa: Centro de Estudos de Históricos - Universidade Nova de Lisboa. MARQUES, A. (2017): "A organização do espaço rural no tempo de D. Afonso Henriques: a morfologia do casal entre os textos e as materialidades". In Barroca, M. (ed.): No Tempo de D. Afonso Henriques: Reflexões sobre o primeiro século português: 195-131. Porto: CITCEM.

MARQUES, J. (1998): "Os municípios na estratégia defensiva dionisina", As relações de fronteira no século de Alcanices. Separata da Revista da Faculdade de Letras da Universidade do Porto, 1: 523-544.

MARTA, I. (1943): Pinhel-Falcão. Celorico da Beira: Tipografia Mondego.

MARTÍ, R (2008a): "Presentación", Fars de l'islam, antigues alimares d'al-Andalus, Barcelona: EDAR, 12-18.

MARTÍ, R. (2008b) - "Los faros en al-Andalus: un sistema original de transmisión de señales", Fars de l'islam, antigues alimares d'al-Andalus, Barcelona: EDAR, 189-218.

MARTÍ, R., FOLCH, C., GIBERT, J. (2007). "Fars i torres de guaita a Catalunya: sobre la problemàtica dels orígens", Arqueologia Medieval. Revista catalana d'arqueològia medieval, n.3: 30-43.

MARTIN BENITO, J. (2002): "Frontera y territorio en el sur del Reino de León (11571212)". Actas del Congresso de História de la Diócesis de Ciudad Rodrigo. I: 39-79.

MARTÍN, J. L., COCA, J. (1987): Fuero de Salamanca. Salamanca: Ediciones de la Diputación de Salamanca.

MARTÍN MARTÍN, J. (1996): "La frontera hispano-portuguesa en la guerra, en la paz y el comercio". In TORRES, A. (coord.): Las relaciones entre Portugal y Castilla en la época de los descubrimientos y la expansión colonial: 29-52. Salamanca: Universidad de Salamanca, Ediciones Universidad de Salamanca. 
MARTÍN MARTÍN, J. (1998): "San Julián del Pereiro entre Calatrava y Alcántara", O Tratado de Alcanices e a importância histórica das terras de Riba Côa. Atas do Congresso Histórico Luso-Espanhol: 181-195. Lisboa: Universidade Católica Editora.

MARTÍN VISO, I. (2000): Poblamiento y estructurassociales en el norte de la Península Ibérica (siglos VI-XIII). Salamanca: Ediciones Universidad Salamanca.

MARTÍN VISO, I. (2005): Una frontera casi invisible: los territorios al norte del sistema central en la Alta Edad Media (siglos VIII-IX). Stvdia Histórica: Histórioa Medieval, 23: 89-114.

MARTÍN VISO, I. (2007a): "Tumbas y sociedades locales en el centro de la Península Ibérica en la Alta Edad Media: el caso de la comarca de Riba Côa (Portugal)", Arqueología y Territorio Medieval, 14: 21-47.

MARTÍN VISO, I. (2007b): Becerro del Monasterio de Nuestra Señora de La Caridad de Ciudad Rodrigo (siglos XII-XIX). Ciudad Rodrigo: Centro de Estudios Mirobrigenses.

MARTÍN VISO, I. (2008): "Una periferia creativa: la articulación del territorio en la comarca de Riba Côa (Portugal) (siglos VI-XI)", Territorio, Sociedad y Poder. Revista de Estudios Medievales, 3: 85-109.

MARTÍN VISO, I. (2009): "Espacios sin Estado Los territorios occidentales entre el Duero y el Sistema Central (siglos VIII-IX)". In MARTIN VISO, I. (ed.): ¿Tiempos oscuros? Territorio y sociedad en el centro de la Península Ibérica (siglos VII-X): 107136. Madrid: Sílex ediciones.

MARTÍN VISO, I. (2011): “Territorios supraldeanos y espacios de producción en el centro de la península ibérica (siglos X-XIII)". In SABATÉ, F., BRUFAL, J. (eds.): Els espais de secà. IV curs internacional d'Arqueologia Medieval: 117-143. Lérida: Pagés Editors.

MARTÍN VISO, I. (2012a): "Enterramientos, Memoria social y paisaje en la Alta Edad Media: Propuestas para una análisis de las tumbas excavadas en roca en el centro-oeste de la Península Ibérica", Zephyrus, 69: 165-187.

MARTÍN VISO, I. (2012b) - "Riba Côa y La Monarquía Leonesa", Actas de las Jornadas celebradas en Benavente, Ciudad Rodrigo y Ponferrada. Benavente. Salamanca: Centro de Estudios Benaventanos "Ledo del Pozo", Centro de Estudios Mirobrigenses e Centro de Estudios Bercianos, 163-184.

MARTÍN VISO, I. (2012c): "Paisajes sagrados, paisajes eclesiásticos: de la necrópolis a la parroquia en el centro de la península ibérica", Reti Medievali Rivista, 13, 2: 2-45. 
MARTÍN VISO, I. (2014): "Castra y elites en el suroeste de la Meseta del Duero postromana". In CATALÁN, R., FUENTES, P., SASTRE BLANCO, J. C. (coord.): Fortificaciones en la tardoantigüedad: élites y articulación del territorio (siglos V-VIII d.C.): $247-274$.

MARTÍN VISO, I. (2015): Después qu'esta çiudad fue destruyda: Ciudad Rodrigo y su comarca en la Alta Edad Media (siglo VI-XI). Ciudad Rodrigo: Centro de Estudios Mirobrigenses.

MARTÍN VISO, I. (2016): "Comunidades locales, lugares centrales y espacios funerarios en la extremadura del Duero altomedieval: las necrópolis de tumbas excavadas en la roca alineadas", Anuario de Estudios Medievales, Madrid: CSIC , 46/2: 859-898.

MARTÍN VISO, I. (2016): "Colapso político y sociedades locales: el Noroeste de la península ibérica (siglos VIII-IX)", Reti Medievali Rivista, 17-2: 335-369.

MARTÍN VISO, I., RUBIO DÍEZ, R., LÓPEZ SÁEZ, J., RUIZ ALONSO, M., PÉREZ DÍAZ, S. (2017): "La formación de un nuevo paisaje en el centro de la península ibérica en el periodo posromano: el yacimiento de La Genestosa (Casillas de Flores, Salamanca)", Archivo Español de Arqueologia, 90: 7-28.

MARTíneZ, G. (1971): "Los Fueros de la familia de Coria Cima Coa". Revista Portuguesa de História, XIII: 343-373.

MARTÍNEZ, S. (2009): "Os marqueses de Castelo Rodrigo e a Nobreza portuguesa na monarquia hispânica: estratégias de legitimação, redes familiares e interesses políticos entre a agregação e a restauração (1581-1651)", Ler História [Online], 57 posto online no dia 01 junho 2016. Consultado no dia 23 setembro 2019 . URL: http://journals.openedition.org/lerhistoria/1807

MARTÍNEZ, S., MATESANZ, P., SÁEZ, P., SÁNCHEZ, C, ARRIBAS, R. (1996): "La continuidad de la Red Viaria de Época Antigua en Época Medieval en el Valle del Tiétar Abulense". In CRIADO DE VAL, M. (coord.): Camineria hispánica: actas del II Congreso Internacional de Caminería Hispánica: 169-184.

MARTINS, A. (2015): "E no Médio Côa? A arte esquemática que ainda resiste: o Abrigo do Ribeira das Casas (Almeida)", Revista Portuguesa de Arqueologia, 18: 41 54.

MARTINS, C. (2000): Relatório Intervenção Arqueológica em Escarigo. Relatório Final dos Trabalhos Arqueológicos. Policopiado. 
MARTINS, J., MEDEIROS A., PILAR, L., TEIXEIRA, C. (1963): Carta Geológica de Portugal. Noticia explicativa da Folha 18-C (Guarda). Lisboa: Serviços Geológicos de Portugal.

MATTOSO, J. (1986): "As relações de Portugal com Castela no reinado de Afonso X O Sábio", Separatas Estudos Medievais, 7:69-94.

MATTOSO, J. (1987): Fragmentos de uma composição medieval. Lisboa: Editorial Estampa.

MATTOSO, J. (1992): "Portugal no reino Asturiano-Leonês". In MATTOSO, J. (ed.): História de Portugal: Antes de Portugal: 543-560. Vol. 1. Lisboa: Círculo de Leitores. MATTOSO, J. (1993): "A Monarquia Feudal: 1096-1325". In MATTOSO, J. (ed.): História de Portugal: 9-312. Vol 1. Lisboa: Círculo de Leitores.

MATTOSO, J. (1995): Identificação de um País. Oposição e Composição. Ensaios sobre as origens de Portugal (1096-1325). Lisboa: Editora Estampa.

MATTOSO, J. (2015): Identificação de um País. Oposição e Composição. Ensaios sobre as origens de Portugal (1096-1325). Lisboa: Temas e Debates. Círculos de Leitores.

MATTOSO, J. (2019): A Escrita da História. Lisboa: Temas e Debates. Círculo de Leitores.

MEIRELES, J. (1997): "O Quaternário do Vale do Côa". In ZILHÃO, J. (ed.): Arte Rupestre e Pré-Histórica do Vale do Côa: 41-54. Lisboa: Ministério da Cultura.

MAXFIELD, V. (1987): "The frontiers: mainland Europe". In WACHER, J. (ed.): The Roman World: 139-197.

MENDONÇA, M. (1998): "D. Dinis e a fronteira sul: o Tratado de Badajoz", Revista da Faculdade de Letras, História Série 2, 15: 1123-1134.

MEYER-HERMANN, R. (2016): "Acerca de la relación (genealógica) entre los fueros de Coria y de Castelo Bom", Revista de Direito da Universidade Lusiada, 15: 137-174. MIRANDA GARCÍA, F. (1993): Roncesvalles Trayectoria patrimonial (siglos XIIXIX. Pamplona: Gobierno de Navarra Departamento de Educación y Cultura.

MONSALVO ANTÓN, J. M. (2003): "Frontera pionera, monarquía en expansión y formación de los concejos de villa y tierra. Relaciones de poder en el realengo concejil entre el Duero y el Tajo (c. 1072-c. 1222)", Arqueología y Territorio Medieval, 10.2: 45-126. 
MONSALVO ANTÓN, J. M. (2005): "Espacios y Fronteras en el discurso territorial del Reino de Asturias (del Cantábrico al Duero en las Crónicas Asturianas)", Studia Historica, Historia Medieval, 23: 43-87.

MONSALVO ANTÓN, J. M. (2007): "Comunales de aldea, comunales de ciudad-ytierra. Algunos aspectos de los aprovechamientos comunitarios en los concejos medievales de Ciudad Rodrigo, Salamanca y Avila". In RODRÍGUEZ, A. (coord.): El lugar del campesino: en torno a la obra de Reyna Pastor: 141-178.

MONTEIRO, H. (2012): A Estrada da Beira: Reconstituição de um traçado medieval. Tese de Mestrado em Arqueologia apresentada à Faculdade de Ciências Sociais e Humanas da Universidade Nova de Lisboa. Policopiado.

MONTEIRO, J., MARTINS, M. (2010): As Cicatrizes da guerra no espaço fronteiriço português: (1250-1450). Coimbra: Palimage.

MORALES PAÍNO, F. (2007): Colonización y feudalización de un Territorio entre Fronteras: El suroeste mirobrigense durante los siglos XII-XIII. Salamanca: Centro de Estudios Mirobrigenses/Ayuntamiento de Ciudad Rodrigo.

MORENO, I. (2012): Vias Romanas de Castilla y León. León: Junta de Castilla y León. MORUJÃO, M. (2010a): A Sé de Coimbra: a instituição e a chancelaria (1080-1325). Lisboa: Fundação Calouste Gulbenkian/Fundação Para a Ciência e Tecnologia.

MORUJÃO, M. (2010b): Testamenta Ecclesiae Portugaliae: 1071-1325. Lisboa: Universidade Católica Portuguesa, Centro de Estudos de História ReligiosaMOUTINHO, A. (2014): Cronologia de Almeida: 1000 anos de história. Séculos XIXXI: de Praça-de-Guerra a Aldeia Histórica de Portugal. Almeida: Santa Casa da Misericórdia de Almeida.

NARBARTE HERNÁNDEZ, J., RODRÍGUEZ LEJARZA, A., SANTERAMO, R., QUIRÓS CASTILLO, J., IRIARTE AVILÉS, E. (2018): "Evidencias de ocupación antigua en núcleos rurales actualmente habitados: el proyecto arqueológico de Aizarna (Gipuzkoa)", Munibe Antropologia-Arkeologia, 69: 239-256.

NETO, J. M. (1975): O Leste do Território Bracarense. Torre Vedras: União

NEVES, D. (2012): Alteração de edifício de habitação na Rua do Amparo, São Vicente - Guarda, Relatório Preliminar, Policopiado.

NEVES, M., ALMEIDA, M. (2002): Igreja de Santa Trindade/ Mosteiro de Nossa Senhora da Coluna. Relatório Intercalar. Policopiado. 
NISSEN-JAUBERT, A. (2006): "Le haut Moyen Âge". In FERDIÈRE, A., MALRAIN, F., MATTERNE, V., MÉNIEL, P., NISSEN-JAUBERT, A. (eds.): Histoire de l'agriculture en Gaule: 141-197. Paris: Éditions errance.

NOCETE CALVO, F. (1989): "El análises de las relaciones Centro/Periferia en el Estado de la Primera Mitad del Segundo Milenio a.n.e. en las Campiñas del Alto Guadalquivir: La Frontera", Arqueologia Espacial: Fronteras, 13: 37-61.

NOGUEIRA, J. (1982): "Riba Côa e a sua ligação histórica ao reino de Portugal", Colecção Scientia Ivridica, XXX: 175-178.

NOGUEIRA, B. (2000): "O espaço eclesiástico em território português (1096-1415)", História Religiosa de Portugal. Formação e Limites da Cristandade. Rio de Mouro: Círculo de Leitores, I: 142-146.

NUNES, J. (2016): "Circunscrições eclesiásticas: arciprestados e freguesias", História da Diocese de Viseu. Viseu: Diocese de Viseu e Imprensa da Universidade de Coimbra, $12-24$.

NUNES, M., CAMEIJO, A. (2005): Programa Guarda Polis - Projecto de Reabilitação Urbana do Largo do Torreão e Área Envolvente. Relatório Preliminar. Policopiado.

NUNES, S., NEVES, M. J. (2008): Centro Histórico de Pinhel. Acompanhamento Arqueológico. Relatório Final. Coimbra: Dryas Arqueologia, Lda. Policopiado.

NUNES, S.; FERREIRA, M. T., NEVES, M. J. (2011): Centro Histórico de Pinhel. Sondagens Arqueológicas. Relatório Final. Coimbra: Dryas Arqueologia, Lda. Policopiado.

NUNES, S., RIBEIRO, C., NEVES, M., WASTERLAIN, S., FERREIRA, M. (2018): "Intervenção Arqueológica no Centro Histórico de Pinhel (Guarda) resultados arqueológicos e paleobiológicos", Al-madan, II série (22) tomo 2: 18-25.

Ogburn, D.E., (2006): “Assessing the level of visibility of cultural objects in past landscapes". Journal of Archaeological Science 33: 405-413.

OSÓRIO, M. (2004a): "Novos contributos para o estudo dos Castelos Velhos (Guarda)", Praça Velha, I a série, 15: 5-15.

OSÓRIO, M. (2004b): Relatório Final dos Trabalhos de Acompanhamento Arqueológico do Projecto de Loteamento dos Castelos Velhos. Policopiado.

OSÓRIO, M. (2006): O povoamento romano do Alto Côa. Guarda: Câmara Municipal da Guarda.

OSÓRIO, M. (2007): EIA - Barragem do Rio Seco - Vale da Mula - Almeida. Relatório de Prospecção. Policopiado 
OSÓRIO, M. (2008): "O urbanismo e a arquitectura do Sabugal Velho (Aldeia Velha, Sabugal). Tentativa de caracterização de uma aldeia fortificada no Riba-Côa dos séculos XII-XIII.", Da Idade Média à Contemporaneidade: Ambientes e musealização. III Congresso de Arqueologia de Trás-os-Montes, Alto Douro e Beira Interior. Foz Côa, IV: $13-21$.

OSTOLAZA, M. I. (1978): Colección diplomática de Santa María de Roncesvalles (1127-1300). Pamplona: Diputación Foral de Navarra, Institución Principe de Viana, Consejo Superior de Investigaciones Científicas.

O'CALLAGHAN, J. F. (1962): “The foundation of the Order of Alcántara, 1176-1218”, The Catholic Historical Review, XLVII: 471-486.

PALACIOS, M. (2005): "El Císter y la fundación de la orden de Alcántara", Cistercium, 238: 197-212.

PALACIOS MARTIN, B., AYALA MARTINEZ, C. (2000): Colección diplomática medieval de la Orden de Alcántara (1157?-1494) de los origenes a 1454. Madrid: Editorial Complutense.

PANIAGUA, E. ÁlVAREZ, A. (2011): "Tumbas excavadas en roca y poblamiento altomedieval en casillas de flores (Salamanca) Primeros resultados a partir de una prospección". In SASTRE BLANCO, J. C., CATALÁN, R., FUENTES, P. (coord.): Arqueología en el valle del Duero. Del Neolítico a la Antigüedad Tardía, nuevas perspectivas: actas de las primeras Jornadas de Jóvenes Investigadores del Valle del Duero: 299-306. Zamora.

PARENTI, R. (1988): "Le tecniche di documentazione per una lettura stratigrafica dell'elevato", Archeologia e restauro dei monumento, 280-304.

PARKER, H. D. (1988): "The unique qualities of a geographic information system: a comentary", Photogrammetic Engineering and Remote Sensing, 54(11): 1547-1540.

PEÑA BOCOS, E. (1995): La atribución social del espacio en la Castilla altomedieval: Una nueva aproximación al feudalismo peninsular. Santander: Universidad de Cantabria.

PEREIRA, D. (2008): O conceito de praça na cidade da Guarda entre a Idade Média e a Idade Moderna. Promontoria, 6: 325-350.

PEREIRA, V. (2003): "Intervenção Arqueológica no Edifício dos Antigos Paços do Concelho, Guarda", Quarto Encontro de Arqueologia Urbana. Amadora: Museu Municipal de Arqueologia da Amadora. PEREIRA, V. (2006): Levantamento Arqueológico Concelho da Guarda. Guarda: Relatório Final. 
PEREIRA, V. (2007a): "A torre velha do primitivo castelo da Guarda", Praça Velha, I série, 22: 13-29.

PEREIRA, V. (2007b) - Intervenção Arqueológica na Rua do Torreão Centro Histórico da GuardA. Relatório Final. Policopiado.

PEREIRA, V. (2010): Intervenção Arqueológica no Âmbito do Projecto de Reabilitação Urbana do Espaço Público Do Centro Histórico da Guarda Zona C. Relatório Final. Policopiado.

PEREIRA, V. (2011): Intervenção Arqueológica No Castro Do Jarmelo (Guarda) Relatório Final 2007/2008. Policopiado.

PEREIRA, V. (2012) - O sítio romano da Póvoa do Mileu (Guarda): Povoamento, estruturas e materiais arqueológicos de uma pequena ciuitas localizada nos confins ocidentais do império romano. Tese de Doutoramento em Arqueologia apresentada à Faculdade de Letras da Universidade de Coimbra. Policopiado.

PEREIRA, V. (2015): Investigação e Valorização da Estação Arqueológica da Póvoa do Mileu (Guarda) - Relatório de Progresso 2014. Policopiado.

PEREIRA, V., CAMEIJO, A. (2013): "Os sistemas defensivos da Guarda Medieval. Contributo para o seu conhecimento". In FERNANDES, I. (ed.): Fortificações e Território na Península Ibérica e no Magreb (Séculos VI a XVI): 435-443. Lisboa: Colibri/Campo Arqueológico de Mértola.

PEREIRA, V. P., CAMEIJO, M. A., MARQUES, A. C. (2006): Projecto de InfraEstruturas do Centro Histórico de Pinhel. Acompanhamento Arqueológico. Relatório Final. Policopiado.

PEREIRA, V., CAMEIJO, A., MARQUES, A. (2011): "Arqueologia no Centro Histórico da Guarda: resultados da intervenção do Torreão". In ALMEIDA, M., CARVAlHO, A., (ed.): Actas do Encontro de Arqueologia e Autarquias: 265-292. Cascais: Câmara Municipal de Cascais/Associaçao Profisional de Arqueólogos.

PEREIRA, V., RAMOS, T. (2016a): Relatório final PIPA 2015 -Levantamento Arqueológico no Concelho da Guarda- Policopiado.

PEREIRA, V., RAMOS, T. (2016b): Intervenção Arqueológica na Área Ajardinada do Solar dos Póvoas (Guarda) Relatório Final. Policopiado.

PEREIRA, V., RAMOS, T., CAMEIJO, A. (2016): Investigação e Valorização da Estação Arqueológica da Póvoa do Mileu (Guarda) - Relatório de Progresso. Policopiado. 
PEREIRA, V., RAMOS, T., ROSA, J. (2018) - Relatório Final Trabalhos Arqueológicos na Avenida Watterbury - Póvoa do Mileu, Guarda. Policopiado.

PEREIRA, V., RAMOS, T. (2019) - "Sequência estratigráfica e materiais cerâmicos do Sítio da Póvoa do Mileu (Guarda, Portugal)", Estudios Humanísticos. Historia, 16: 133155.

PERESTRELO, M. (2003): A Romanização na Bacia do Rio Côa. Vila Nova de Foz Côa: Parque Arqueológico do Vale do Côa.

PERESTRELO, M. E., FERREIRA, M. C. (2002): "Fortificações e caminhos medievais no Médio Côa". In FERNANDES, I. (coord.): Mil Anos de Fortificações na Península Ibérica e no Magreb (500 - 1500): Actas do Simpósio Internacional sobre Castelos: 885893.

PÉREZ, I. (2014): "Aceifas andalusíes y cristianas a través de la mitad sur del valle del Duero. Un estudio cuantitativo", Estudios Medievales Hispánicos, 3: 71-128.

PÉREZ, I. (2018): Tierra de Nadie. Sociedad y Poblamiento entre el Duero y el Sistema Central (siglos VIII-XI). Madrid: Libros Mablaz.

PÉREZ ÁlVAREZ, M. (1992): Fuentes árabes de Extremadura. Cáceres: Universidad de Extremadura.

PINA, F. (2018): "Cabeço da Senhora das Preces (Ruvina): medidas compensatórias de minimização e sondagens arqueológicas (2018)", Sabucale, 9: 55-62.

PIZARRO, J. (1997): Linhagens medievais portuguesas: genealogias e estratégias 12791325. Tese de Doutoramento em História apresentada à Faculdade de Letras da Universidade do Porto. Policopiado.

PIZARRO, J. (2007): "O regime senhorial na fronteira do nordeste português. Alto Douro e Riba Côa (séculos XI-XIII)", Hispania. Revista Española de Historia, LXVII: 849-880.

POLICARPO, J. (1998): "A Cidade Romana e a Diocese de Caliábria", O Tratado de Alcanices e a importância histórica das terras de Riba-Côa. Actas do Congresso Histórico Luso-Espanhol, Lisboa: Universidade Católica Editora, 107-114.

PRATA, S. (2012): As Necrópoles alto medievais da Serra de São Mamede (Concelhos de Castelo de Vide e Marvão). Tese de Mestrado apresentada à Faculdade de Ciencias Sociais e Humanas da Universidade Nova de Lisboa. Policopiado.

PRATA, S. (2014): "Espaços funerários alto medievais no Norte da Serra de São Mamede (Portalegre, Portugal): uma proposta de organização espacial", Revista Arkeogazte, 4: 261-279. 
PRATA, S. (2017): "Objectos arqueológicos alto medievais em contexto doméstico: o caso da Tapada das Guaritas (Castelo de Vide, Portugal)", Mediaeval Sophia, 19: 413429.

PRATA, S. (2018): Arqueologia do povoamento rural alto medieval no território de Castelo de Vide (siglos V - VIII). Tese de Doutoramento em Arqueologia apresenta à Universidad de Salamanca. Policopiado.

PRATA, S., CUESTA-GÓMEZ, J. F. (2017): "Antes de vide e do castelo: arqueologia da Alta idade Média no território de Castelo de Vide". In COSTA, A., ANDRADE, A., TENTE, C. (ed.): O papel das pequenas cidades na Construção da Europa medieval. 17: 143-159. Lisboa: IEM - Instituto de Estudos Medievais / Câmara Municipal de Castelo de Vide.

QUINTA, A. L. (2008): A fortaleza de Almeida: uma perspectiva arquitectónica. Almeida: Câmara Municipal de Almeida.

QUIRÓS CASTILlO, J. A. (2007): "Las aldeas de los historiadores y de los arqueólogos en la Alta Edad Media del norte peninsular", Territorio, Sociedad y Poder, Revista de Estudios Medievales, 2: 65-87.

QUIRÓS CASTILLO, J. A. (2009): ¿Por qué excavar en grandes extensiones? Arqueología de los despoblados alaveses y el estudio de la aldea de Zornoztegi (Salvatierra-Agurain)", Actas del Congreso 750 aniversario de la fundación de la villa de Salvatierra. San Sebastián, 375-397.

QUIRÓS CASTILLO, J. A. (2013): "El poblamiento rural de época visigoda en Hispania. Arqueología del campesinado en el interior peninsular", Debates de Arqueologia Medieval 6, Bilbao: Universidad del País Vasco.

RAMOS, J. (2003): São Pedro do Rio Seco - Contributo para uma monografia. São Pedro do Rio Seco: Junta de Freguesia de São Pedro do Rio Seco.

RAMOS, T. (2014): O Castro do Jarmelo em época medieval: contributo da arqueologia para o seu estudo. Lisboa. Tese de Mestrado em Arqueologia apresentada à Faculdade de Ciências Socias e Humanas Universidade Nova de Lisboa. Policopiado.

RAMOS, T. (2016): "A lot of fragments so few results? Some reflections based on the analysis of big containers from Jarmelo (Guarda, Portugal)", Conference Proceedings First International Topical Congressof the AIECM3 Jars and large containers between the Middle Ages and the Modern Era, 43-47, Aix-en-Provence: Aix Marseille Univ, CNRS, LA3M. 
RAMOS, T. (2018): "A Póvoa do Mileu (Guarda) no final do mundo romano", La Raya en los inicios del medievo. Catálogo de la exposición: Fortificaciones, poblados y pizarras, 84-107.

RAMOS, T. (2018): "Nem só com castelos se defendeu a fronteira: atalaias e povoados fortificados na margem esquerda do Médio Côa". In ROSAS, L., SOUSA, A., BARREIRA, H. (ed.): Genius Loci: lugares e significados: 145-158. Porto: CITCEM Centro de Investigação Transdisciplinar Cultura, Espaço e Memória.

RAMOS, T. (2019): Relatório de Prospecção Arqueológica no Médio Côa (2018). Policopiado.

RAMOS, T., PEREIRA, V. (2018) - "Entre Velhos e Novos Dados. Contributos para o estudo da Póvoa do Mileu (Guarda, Portugal) na Antiguidade Tardia". In HERNÁNEDEZ GUTIÉRREZ, N., LARRAZÁBAL GALARZA, J., PORTERO HERNÁNDEZ, R. (ed.): Atas das VI Jornadas de Arqueologia do Vale do Douro: 475488. Porto: Glyphos.

RAMOS, T., RICARDO, S. (2020): Relatório Final Intervenção Arqueológica no Âmbito Projecto de Legalização e Alteração de Armazém Para Arrumos (Senhora da Coluna, Pinhel). Policopiado.

RAMOS, T., CAMEIJO, A., PEREIRA, V. (no prelo): "A Torre Velha da Guarda: De torre românica a vazadouro de detritos". Actas Colóquio Internacional Pequenas Cidades e Ambiente (da Idade Média à Época Contemporânea), Castelo de Vide 2018.

RAMOS, T., RICARDO, S., JACINTO, G. (no prelo): "Voluntariado Jarmelo", 1056 In-Folio, Boletim do Museu da Guarda, 3.

RANKOV, B. (2005): "Do Rivers make good frontiers?". In VISY, Z. (ed.): Limes XIX: Proceedings of the XIXth International Congress of Roman Frontier Studies: 175181. Pécs: Hungary.

RAU, V. (1982): Sesmarias medievais portuguesas. Lisboa: Presença.

RAUX, S. (1998): "Méthodes de quantification du mobilier céramique. Etat de la question et pistes de réflexion". In ARCELIN, P., TUFFREAU-LIBRE, M. (dir.): Actes de la table ronde du Centre archéologique européen du mont Beuvray: 2: 11-16.

REAL, M. (2005): "Mosteiro de Fráguas no contexto do pré-românico da Beira Interior (Portugal)". In BARROCA, M., FERNANDES, C. (coord.): Muçulmanos e Cristãos entre o Tejo e o Douro (séculos VIII a XIII): 275-292. Palmela: Câmara Municipal de Palmeia e Faculdade de Letras da Universidade do Porto. 
REAL, M. (2013): "O Castro de Baiões terá servido de atalaia ou castelo, na Alta Idade Média? Sua provável relação com o refúgio de Bermudo Ordonhes na Terra de Lafões", Revista da Faculdade de Letras, Ciências e Técnicas do Património, XII: 203-230.

REAL, M. (2018): "O papel das elites na definição do território. A sua presença no processo de senhorialização da "fronteira beirã”". In TENTE, C. (ed.): Do Império ao Reino. Viseu e o território entre os séculos IV a XII: 297-344. Viseu: Câmara Municipal de Viseu.

REDENTOR, A., CARVAlHO, P. (2017): "Continuidade e mudança no Norte da Lusitânia no tempo de Augusto", Gerión. Revista de Historia Antigua, 35: 417-441.

REI, A. (2002): "Târiq ibn Ziyâd e o seu exército em Almeida e na Cidade de Ammaia (Marvão) em finais de 711 - inícios de 712", Ibn Marúan, 12: 159 - 168.

REI, A. (2005a): "O Gharb al-Andalus em dois geógrafos árabes do século VII / XIII: Yâqût al-Hamâwî e Ibn Sa'îd al-Maghribî", Medievalista, 1: 1-22.

REI, A. (2005b): "Almeida e a Cidade da Amaya (Marvão) no itinerário de Târiq ibn Ziyâd e do seu exército em fins de 711 - inícios de 712". In BARROCA, M., FERNANDES, I. (ed.): Muçulmanos e Cristãos entre o Tejo e o Douro (Sécs. VIII a XIII): 85-90. Palmela: Câmara Municipal de Palmela e Universidade do Porto.

REIS, B. dos (1934): Livro da fundação do Mosteiro de Salzedas. Lisboa: Imprensa Nacional - Casa da Moeda.

REIS, M. P. (2002): Villa Romana do Prado Galego (1ª Campanha Arqueológica/ 2002) Relatório Final. Policopiado.

REIS, M. P. (2003): Igreja de Santa Maria do Castelo (Pinhel). Acompanhamento e sondagens arqueológicas. Relatório Final. Policopiado.

REIS, M. P. (2005): Estação romana do Prado Galego (Valbom, Pinhel). Estudo de um exemplo de ocupação rural romana. Relatório progresso 1. Relatório Final. Policopiado. REIS, M. P. (2007): Villa Romana do Prado Galego. $3^{\text {a }}$ Campanha de escavação (2005/2006) $2^{\circ}$ Relatório ( $1^{\circ}$ ano /PNTA). Policopiado.

REIS, M. P. (2008): Villa Romana do Prado Galego. Campanha de escavações 2008. PNTA 2006/2009. Relatório de Progresso 2. Policopiado.

RÊPAS, L. (2000): Quando a Nobreza traja de branco: A Comunidade Cisterciense de Arouca durante o Abadessado de D. Luca Rodrigues, 1286-1299. Tese de Mestrado em História apresentada à Faculdade de Letras da Universidade de Coimbra. Policopiado. RIBEIRO, C. (2013): Granito do passado: Análise antropológica de uma série osteológica da época medieval/moderna proveniente de Pinhel (Guarda). Tese de 
Mestrado em Antropologia apresentada à Faculdade de Ciências e Tecnologias Universidade de Coimbra. Policopaida.

Ribeiro, O. (1986): Portugal, o Mediterrâneo e o Atlântico: esboço de relações. Lisboa: Livraria Sá da Costa.

RIBEIRO, O. (1987): Geografia de Portugal. Lisboa: João Sá da Costa.Vol. 1.

RIBEIRO, O., LAUTENSACH, H., DAVEAU, S. (1989): Geografia de Portugal. O povo português, III. Lisboa: Edições João Sá da Cunha.

RICARDO, S. E RAMOS, T. (2019): Acompanhamento Arqueológico Projeto de Plantio de Vinha na Quinta do Prado- Galego (Pinhel). Relatório Final. Policopiado.

RILEY, C. (1991): "A guerra e o espaço na fronteira medieval beirã. Uma abordagem preliminar", Revista de Ciências Históricas, VI: 145-159.

RODRIGUES, A. (1966): "A propósito do templo romano de Almofala", Beira Alta, 25 (4): 619-622.

RODRIGUES, A. (1980): "Antiguidades de Argomil". Altitude, II Série, Ano 1, 1: 99 100.

RODRIGUES, A. (1981): "O Tratado de Alcanizes e as terras de Riba Côa. Uma identidade geográfica, histórica e social à espera de conveniente valorização", Revista Altitude, 3-2. ${ }^{\mathrm{a}}$ série: $7-24$.

RODRIGUES, A. (2000): Guarda: Pré-História, História e Arte: Monografia. Guarda: Santa Casa da Misericórdia.

RODRIGUES, A. (2010): Almeida: Da Pré-história Aos Nossos Dias - Memórias. Almeida: Câmara Municipal de Almeida.

ROMÃO, J. (2012): No encalço do passo do Homem medieval: as vias de comunicação do antigo termo e atual concelho de Tomar. Tese de Mestrado em Arqueologia apresentada à Faculdade de Ciências Sociais e Humanas da Universidade Nova de Lisboa. Policopiado.

ROWLANDS, M. (1987): "Centre and periphery: A review of concepts". In ROWLANDS, M., LARSEN, M., KRISTIANSEN, K. (ed.): Centre and Periphery in the Ancient World: 1-11. Cambridge: Cambridge University Press.

RUBIO, R. (2013): "Geografia funeraria, comunidades campesinas y articulación territorial post-romana al suroeste de Salamanca". In COMPAÑY, G., FONTE, J., GÓMEZ-ARRIBAS, B., MORAGÓN, L., SEÑORAN, J. (ed.): Actas de las V Jornadas de Jóvenes en Investigación Arqueológica. Arqueología para el siglo XXI: 119-125. 
RUBIO, R. (2015): Arqueología, paisaje y territorio postro-mano. Las tumbas excavadas en roca en el occidente del Campo de Ciudad Rodrigo (Salamanca). Ciudad Rodrigo: Centro de Estudios Mirobrigenses.

RUIVO, J S., CARVALHO, P. (1996): "Uma via romana na Serra da Estrela: o troço Valhelhas-Mangualde”, Materiais, 2- II. ${ }^{\text {a }}$ série: 77-88.

RUIZ RODRIGUEZ, A., MOLINOS, M. (2008): "Las fuentes del Guadalquivir. Límites y fronteras para el norte de la Bastetania". In ADROHER, A., BLÁNQUEZ, J. (eds.): Actas del Primer congreso Internacional de Arqueologia Ibérica Bastetana: 5172.

SACK, R. D. (1986): Human Territoriality: Its Theory and History. Cambridge: Cambridge University Press.

SALVADO, L., COUTINHO, V. (1999): Castelo Rodrigo: Ruinas Misteriosas. Castelo Rodrigo: Câmara Municipal de Figueira de Castelo Rodrigo.

SALVATIERRA CUENCA, V., ARGÜELlES MÁRQUEZ M., MORENO ONORATO, A. (1989): "Visibilidad y control: un problema de fronteras: el caso nazarí en el sector Montefrío-Moclín", Arqueología Espacial, 13: 137-150.

SÁNCHEZ HERREO, J. (1999): El tratado de Alcañices: ponencias y comunicaciones de las Jornadas conmemorativas del VII centenario del Tratado de Alcañices (12971997). Zamora y Alcañices. Zamora: Fundación Rei Afonso Henriques.

SANCHEZ-ORO, J. (1997): Orígenes de la Iglesia en la Diócesis de Ciudad Rodrigo: Episcopado, Monasterios y Órdenes Militares. Ciudad Rodrigo: Centro de Estudios Mirobrigenses.

Sánchez-Pardo, J. C. (2014): "Sistema de Señales a Larga Distancia. Estudio de los topónimos "faro", "facho" y "meda" en el noroeste peninsular". In CATALÁN, R., FUENTES, P., SASTRE, J. C. (eds.): Las Fortificaciones en la TardoAntiguedad. Élites y articulación del territorio (sigloes V - VIII d.C.): 417-424.

SÁNCHEZ-PARDO, J. C., BLANCO-ROTEA, R., SANJURJO-SÁNCHEZ， J., BARRIENTOS-RODRÍGUEZ, V. (2019): "Reusing stones in medieval churches: a multidisciplinary approach to San Martiño de Armental (NW Spain)", Archaeological and Anthropological Sciences, 11: 2073-2096.

SANTOS, C., CRAVO, S. (2014): Praça-Forte de Almeida. Relatório Acompanhamento Arqueológico. Policopiado.

SANTOS, F., PERPÉTUO, J. (2004): Projecto do Loteamento dos Castelos Velhos (Guarda) Análise Patrimonial do Subsolo. Relatório final. Policopiado. 
SANTOS, J. (2018): Costumes e Foros de Castelo Bom. Lisboa: Colibri e Academia Portuguesa de História.

SARAIVA, A. (2007): Catálogo do Arquivo do Museu de Grão Vasco. Viseu: Instituto dos Museus e da Conservação [suporte DVD]

SARAIVA, A. (2010): "Viseu - do governo condal ao reinado de D. Afonso Henriques (1096-1185). A renovação de um perfil urbano", Revista de História da Sociedade e da Cultura, 10/1: 11-36.

SERRANO-PIEDECASAS, L., MUÑOZ, M. A. (1994): "San Felices de los Gallegos (Salamanca): Análisis Estratigráfico de la Cerca Vieja", Studia Histórica, História Medieval, 14: 105-131.

SHILS, E. (1975): Center and Periphery: Essays in Macrosociology. Chicago e Londres: University of Chicago Press.

SILVA, C. (2002): O Mosteiro de S. Vicente de Fora: a comunidade regrante e o património rural (Séculos XII-XIII). Lisboa: Colibri.

SILVA, J. (1992): Monografia do Concelho de Figueira de Castelo Rodrigo. Gouveia: Gráfica Gouveia.

SILVA, M. (2006): Scriptores et Notatores: A Produção Documental da Sé do Porto (1113-1247). Tese de Mestrado em História apresenta à Faculdade de Letras da Universidade do Porto. Policopiado.

SILVA, R. (2015): "Traços mouriscos" na cerâmica do século XV do antigo Paço Episcopal de Coimbra (Museu Nacional de Machado de Castro)". In GONÇALVES, M. J., GÓMEZ-MARTÍNEZ, S. (coord.): Actas do X Congresso Internacional A cerâmica medieval no mediterrâneo: Silves: 924-927, Câmara Municipal de Silves, Campo Arqueológico de Mértola.

SILVA, T. (2012): "Contributos para a História de Almeida e do seu castelo (Século VIII-XIII)", CEAMA, 8: 60-71.

SOLAUN BUSTINA, J. (2005): La Cerámica Medieval En El País Vasco (Siglos VIIIXIII). Vitoria : Servicio Central de Publicaciones del Gobierno Vasco.

STARK, M. (1998): "Technical choices and social boundaries in material culture patterning: an introduction". In STARK, M. (ed.): The Archaeology of Social Boundaries: 1-11.

TAROUCA, C. (1952): Crónica dos Sete primeiros Reis de Portugal. Vol II. Lisboa: Academia Portuguesa de História. 
TAVARES, M. (2013): Costumes e Foros de Riba-Côa - Normativa e Sociedade. Tese de Doutoramento em História apresentada à Universidade de Lisboa. Policopiado.

TEIXEIRA, A. (2008): Sondagens arqueológicas no Castelo de Almeida e envolvente: Síntese de resultados (2007). CEAMA. Centro de Estudos de Arquitectura Militar de Almeida. Almeida, 2: 44-55.

TEIXEIRA, A. (2009): Almeida - Candidatura das Fortificações Abaluartadas da Raia Luso-Espanhola a Património Mundial - Unesco. Almeida: Câmara Municipal de Almeida, 53-59.

TEIXEIRA, A. (2010): O Castelo de Almeida: origem medieval, reformas manuelinas e reutilização moderna. Projecto de investigação e valorização arqueológica. Relatório de progresso (2009). Policopiado.

TEIXEIRA, A. (2011): O Castelo de Almeida: origem medieval, reformas manuelinas e reutilização moderna. Projecto de investigação e valorização arqueológica. Relatório de progresso (2010). Policopiado.

TEIXEIRA, A. (2012) O Castelo de Almeida: origem medieval, reformas manuelinas e reutilização moderna. Projecto de investigação e valorização arqueológica. Relatório Final (2014). Policopiado.

TEIXEIRA, A. (2013): O Castelo de Almeida: Arqueologia de um espaço de guerra multissecular. Almeida: Câmara Municipal de Almeida.

TEIXEIRA, A. (2014): O Castelo de Almeida: origem medieval, reformas manuelinas e reutilização moderna. Projecto de investigação e valorização arqueológica. Relatório de progresso (2012). Policopiado

TEIXEIRA, A., COSTA, T. (2009): Relatório final dos Trabalhos Arqueológicos de Acompanhamento no Baluarte de São João de Deus - Praça-Forte de Almeida (Almeida, Guarda).

TEIXEIRA, A., COSTA, T. (2011): Acompanhamento Arqueológico do Arranjo Urbanístico do Largo 25 de Abril em Almeida (Guarda). Relatório Final. Policopiado TEIXEIRA, A., COSTA, T. (2012): Acompanhamento Arqueológico da Regeneração Urbana da Zona Baixa da Vila - Redes de Média Tensão e de Gás em Almeida (Guarda). Relatório Final. Policopiado.

TEIXEIRA, A., COSTA, T. (2013) - Acompanhamento Arqueológico da Ciclovia em Almeida (Guarda) - Revelim da Cruz e Portas de São Francisco. Relatório Final. Policopiado. 
TEIXEIRA, A., COSTA, T., GIL, L. (2013): "Fortificação, espaço conventual, saneamento e circulação na Idade Moderna em Almeida (Guarda): resultados de intervenções arqueológicas", Revista Portuguesa de Arqueologia, 375-387.

TEJADO SEBASTIÁN, J. M. (2011): Arqueologia y gestión del territorio en el Alto Valle del Iregua. El castro de "El Castillo de los Monjes" (Lumbreras, La Rioja). Logroño: Universidad de La Rioja.

TEJERIZO, C. (2016): Arqueología del Campesinado Medieval en la Cuenca del Duero (SS. V-VIII D.C.). Doutoramento em Arqueologia Vitoria-Gasteiz.

TELES, C., TELES, J (1981): Levantamento toponímico e arqueológico do Concelho de Almeida. Coimbra: Instituto de Arqueologia da Faculdade de Letras.

TENTE, C., PRATA, S., CORDERO RUIZ, T., CUESTA-GÓMEZ, F., MEIRA, C., SOUZA, G., TERESO, S., RAMOS, T., RICARDO, S., VELOSO, J., CASTRO, R. (no prelo): "A Alta Idade Média no interior centro-norte português. Perspectivas comparadas e agenda para o futuro". In MARQUES, J. (ed.): Actas Colóquio a Península Ibérica entre os Séculos V- X. Continuidade, Transição e Mudança. Lisboa: Associação de Arqueólogos Portugueses.

TENTE, C. (2007): A ocupação altomedieval da Encosta Noroeste da Serra da Estrela, Trabalhos de Arqueologia, 47, Lisboa, IPA.

TENTE, C. (2009): "Viver em autarcia. A organização do território do alto Mondego (Portugal) entre os séculos V a X". In MARTíN VISO, I. (ed.): ¿Tiempos oscuros? Territorio y sociedad en el centro de la Península Ibérica (siglos VII-XI): 137-157. Madrid: Sílex.

TENTE, C. (2010): Arqueologia Medieval Cristã no Alto Mondego. Ocupação e exploração do território nos séculos V a XI. Tese de Doutoramento em Arqueologia apresentada à Faculdade de Ciências Sociais e Humanas da Universidade Nova de Lisboa. Policopiado.

TENTE, C. (2012): "Settlement and society in the Upper Mondego Basin (centre of Portugal) between the 5th and the 11th centuries", Archeologia Medievale, 39: 385-398. TENTE, C. (2015): "Tumbas rupestres en el Alto Mondego (Guarda, Portugal). Patrones de distribución, significados y construcción del paisaje rural altomedieval", MUNIBE ANTROPOLOGIA-ARKEOLOGIA, 66: 271- 290.

TENTE, C. (2016): "A geografia diocesana entre os séculos VI a 1147". In PAIVA, J. P. (coord.): História da Diocese de Viseu: 23-42. Viseu: Diocese de Viseu / Imprensa da Universidade de Coimbra. 
TENTE, C. (2017): "Rock-cut graves and cemeteries in the medieval rural landscape of the Viseu region (Central Portugal)". In BIS-WORCH, C., THEUNE, C. (eds.): Religion, cults \& rituals in the medieval rural environment: 215-225. Ruralia, XI. Leiden: Sidestone Press.

TENTE, C. (2018a): "Os últimos 30 anos da Arqueologia Medieval Portuguesa (19872017)". In QUIRÓS CASTILLO, J. A. (ed.): Treinta años de Arqueologia Medieval en España: 49-94. Oxford: Access Archeopress.

TENTE, C. (2018b): Do Império ao Reino. Viseu e o território entre os séculos IV a XII. Viseu: Câmara Municipal de Viseu.

TENTE, C., LOURENÇO, S. (1998): "Sepulturas medievais escavadas na rocha dos concelhos de Carregal do Sal e Gouveia: estudo comparativo", Revista Portuguesa de Arqueologia, 1 (2): 191-218.

TENTE, C., CARVALHO, A. (2011): "The establishment of radiocarbon chronologies for early Medieval sites: a case study from the Upper Mondego Valley (Guarda, Portugal)", Munibe Antropologia-Arkeologia, 62: 461 -468. TENTE, C., MARTÍN VISO, I. (2018): "O Castro de Tintinolho em época pós-romana". In MARTìN VISO, I. (ed.): Fortificaciones, poblados y pizarras: la raya en los inícios del Medievo: 137-157. Ciudad Rodrigo: Ayuntamiento de Ciudad Rodrigo.

TENTE, C., LANTES, O., PRIETO, P. (2014): "Produção cerâmica nos séculos IX a XI na região do Alto Mondego (Portugal)". In DE MAN, A., TENTE, C. (coord.): Estudos de Cerâmica Medieval - O Norte e Centro de Portugal. Séculos XI a XII: 109-139. Lisboa: IEM - Instituto de Estudos Medievais.

TENTE, C., CORDERO RUIZ, T., CASTRO, R. (2018): "A configuração territorial da Diocese Viseense no período Suevo-Visigodo". In TENTE, C. (coord): Do Império ao Reino. Viseu e o território entre os séculos IV a XII: 179-194. Viseu: Câmara Municipal de Viseu.

TORRES Y TAPIA, A. (1763) - Crónica de la orden de alcántara. Tomo 1 Madrid: Imprenta de Don Gabriel Ramírez.

VARANDAS, J. (2003): "«Bonus Rex» ou «Rex Inutilis» as periferias e o centro. Redes de Poder no Reinado de D. Sancho II (1223-1248)". Tese de Doutoramento em História apresentada à Faculdade de Letras da Universidade de Lisboa. Policopiado.

VAZ, J. (1975): "O Tratado de Alcanizes", Beira Alta, 34-4: 393-427.

VELO Y NIETO, G. (1968): Castillos de Extremadura: tierra de conquistadores (1 ${ }^{\mathrm{a}}$ edición). Madrid: Escuelas Profesionales "Sagrado Corazón de Jesús". 
VENTURA, L. (1992): A nobreza de corte de Afonso III. Tese de Doutoramento em História apresentada à Faculdade de Letras da Universidade de Coimbra. Policopiado. VENTURA, L. (2006): Chancelaria de D. Afonso III. Livro $1^{\circ}$ e $2^{\circ}$. Coimbra: Imprensa da Universidade.

VENTURA, L., MATOS, J. (2010): Diplomatário da Sé de Viseu (1078-1278). Coimbra: Instituto de Estudos Medievais, Centro de História da Sociedade e da Cultura, Imprensa da Univ. de Coimbra.

VICENTE, A. (1996): "A fronteira de Riba Côa no tempo de D. Afonso Henriques" Actas 2. ${ }^{\circ}$ Congresso Histórico de Guimarães. A política portuguesa e as suas relações exteriores. Guimarães: Câmara Municipal de Guimarães. 223-231.

VICENTE, A. (1997): Santa Maria de Aguiar, um Mosteiro de Fronteira: Património Rural e Paisagem Agrícola: Séculos XII-XIV. Tese de Mestrado em História apresentada na Faculdade de Letras da Universidade de Lisboa.

VILAR, H. (1996): Uma fronteira entre poderes: as dioceses de Évora e da Guarda no nordeste alentejano, Revista de Guimarães, 106: 251-274.

VIEIRA, M. (2005): "Subsídios toponímicos para o conhecimento da influência muçulmana a sul do Douro". In BARROCA, M., FERNANDES, I. (ed.): Muçulmanos e Cristãos entre o Tejo e o Douro (Sécs. VIII a XIII): 53-67. Palmela: Câmara Municipal de Palmela e Universidade do Porto.

VIGIL-ESCALERA GUIRADO, A. (1999): "Evolución de los morfotipos de cerámica común de un asentamiento rural visigodo de la Meseta (Gózquez de Arriba, San Martín de la Vega, Madrid)", Revista Digital Arqueohispania, $n^{\circ} 0$.

VIGIL-ESCALERA GUIRADO, A. (2009): "Apuntes sobre la genealogía política de aldeasy granjas altomedievales". In MARTÍN VISO, I. (ed.): ¿Tiempos oscuros? Territorio y sociedad en el centro de la península Ibérica (siglos VII-X): 31-44. Salamanca: Sílex universidad.

VIGIL-ESCALERA GUIRADO, A., QUIRÓS CASTILlO, J. A. (2011): "Early medieval rural societies in north-western spain: archaeological reflections of fragmentation and convergence". In ESCALONA, J., REYNOLDS, A. (coord.): Scale and scale change in the Early Middle Ages: exploring landscape, local society, and the world beyond: 33-60.

VIGUERA, M. M. (1998): "En torno a Riba Coa y al-Andalus", O Tratado de Alcanices e a importância histórica das terras de Riba-Côa: Actas do Congresso Histórico LusoEspanhol, Lisboa: Universidade Católica, 147-168. 
VITERBO, Fr. J. (1749): Elucidário. Tomo II, Lisboa: Offi. de Simão Thaddeo Ferreira e Typ Regia Silviana.

ZAMORA RODRIGUEZ, F., ALVARÉZ SANTOS, J., CUNHA, A., DIAZ MARCILLA, F. (2016): "Reflexiones sobre la Frontera a lo largo de la Historia". In ZAMORA RODRIGUEZ, F., ALVARÉZ SANTOS, J., CUNHA, A., DIAZ MARCILLA, F. (coord.): Historias de Frontera. Fronteras com Historia: 4-13. Lisboa: CHAM - Centro de História d'Aquém e d'Além Mar. Faculdade de Ciências Sociais e Humanas / Universidade NOVA de Lisboa Universidade dos Açores.

WHITTAKER, C. (2004): Rome and its frontiers: the dynamics of empire. Londres e Nova Iorque: Routledge Taylor \& Francis Group.

WALLERSTEIN, I. (1974): The Modern World-System. Capitalist Agriculture and the Origins of the European World-Economy in the Sixteenth Century. Vol. I, New York/London: Academic Press.

WALlERSTEIN, I. (1980): The Modern World-System. Mercantilism and the Consolidation of the European World-Economy, 1600-1750. Vol. II, New York: Academic Press.

WALLERSTEIN, I. (1989): The Modern World-System. The Second Great Expansion of the Capitalist World-Economy, 1730-1840's. Vol. III. San Diego: Academic Press.

WILLIAMS, H. (2006): Death and memory in early medieval Britain. Cambridge: Cambridge University Press.

WHITTAKER, C. (2000): "Frontiers". In BOWMAN, A., GARNSEY, P., RATHBONE, D. (eds.): The Cambridge Ancient History, The High Empire: 293-319. WHITTAKER, C. (2004): Rome and its frontiers: The dynamics of empire. Londres e Nova Iorque: Routledge Taylor and Francis Group.

ZADORA-RIO, E. (2005): “Territoires paroissiaux et construction de l'espace vernaculaire”, Médiévales, Volume 49, Issue 2: 105-120. 